\begin{tabular}{|l|c|c|c|r|}
\hline $\begin{array}{l}\text { Cuadernos de Investigación Geográfica } \\
\text { Geographical Research Letters }\end{array}$ & 2017 & N $^{\circ} 43(2)$ & pp. 667-696 & $\begin{array}{r}\text { ISSN 0211-6820 } \\
\text { eISSN 1697-9540 }\end{array}$ \\
\hline
\end{tabular}

DOI: http://doi.org/10.18172/cig.3209

(C) Universidad de La Rioja

\title{
ACROSS THE ARID DIAGONAL: DEGLACIATION OF THE WESTERN ANDEAN CORDILLERA IN SOUTHWEST BOLIVIA AND NORTHERN CHILE
}

\author{
D. WARD*, R. THORNTON, J. CESTA
}

Dept. of Geology, University of Cincinnati, Cincinnati, OH 45221 USA

\begin{abstract}
Here we review published cosmogenic records of glaciation and deglaciation from the western cordillera of the arid subtropical Andes of northern Chile and southwest Bolivia. Specifically, we examine seven published studies describing exposure ages from moraines and glaciated bedrock spanning the glaciological Arid Diagonal, the region of the dry Andes where there is no clear evidence for glaciation over at least the last global glaciation. We also present new cosmogenic ${ }^{36} \mathrm{Cl}$ exposure ages from two previously undated sets of moraines in the deglaciated region near $22^{\circ} \mathrm{S}$. Taken together, these records indicate that the most extensive regional glaciation occurred ca. 35-45 ka, followed by slow, punctuated retreat through the global last glacial maximum, and rapid retreat after 15-17 ka. In the vicinity of the large Altiplanic lakes that existed during the late glacial stage, the 15-17 ka moraines overrode the earlier moraines, whereas elsewhere regionally, on both sides of the Arid Diagonal, late glacial wet periods are represented only by less-prominent moraines in more retracted positions.
\end{abstract}

\section{A Través de la Diagonal Árida: la deglaciación de la Cordillera Andina Occidental en el suroeste de Bolivia y el norte de Chile}

RESUMEN. En este trabajo se revisan los registros cosmogénicos de la glaciación y deglaciación publicados previamente sobre la cordillera occidental de los Andes subtropicales áridos del norte de Chile y el suroeste de Bolivia. Específicamente, se examinan siete estudios que describen las edades de exposición de las morrenas y el sustrato glaciado desde la zona glaciológica Diagonal Árida, hasta la región de los Andes secos, donde no hay evidencias claras de glaciación desde al menos la última glaciación global. También se presentan nuevas dataciones cosmogénicas de exposición de ${ }^{36} \mathrm{Cl}$ en dos conjuntos de morrenas no datados previamente de la zona deglaciada sobre los $22^{\circ} \mathrm{S}$. Considerados en conjunto, estos registros indican que la glaciación regional más extensa comenzó ca. 35-45 ka, seguida de un retroceso lento y con interrupciones durante el último máximo glaciar global, y un rápido retroceso después de $15-17 \mathrm{ka}$. En las inmediaciones de los grandes lagos altiplánicos tardiglaciares, las morrenas de 15-17 ka sobresalian de las morrenas anteriores, mientras que en otras regiones, a ambos lados de la 
Diagonal Árida, los periodos húmedos tardiglaciares están representados sólo por las morrenas menos destacadas y en posiciones más retraídas.

Key words: deglaciation, Andes, cosmogenic dating, moraines, paleoclimate.

Palabras clave: deglaciación, Andes, datación cosmogénica, morrenas, paleoclimatología.

Received: 22 December 2016

Accepted: 23 March 2017

* Corresponding author: Dylan Ward, Department of Geology, University of Cincinnati, Cincinnati, OH 45221, USA. E-mail address: dylan.ward@uc.edu

\section{Introduction}

The Andean Orogen (Andes) stretches $\sim 7000 \mathrm{~km}$ along the western subduction margin of South America, and nearly this entire length has extant glaciers or has been glaciated in the Pleistocene. The history of glaciation and deglaciation along the length of the Andes can reveal linkages between modern climate systems as well as the global progression of regional climate changes during major climate transitions (e.g., Rodbell et al., 2009; Denton et al., 2010). Along the strike of the Andes, the large-scale patterns of major global (Hadley) circulation features change, and are modulated by regional systems (e.g., the El Niño/Southern Oscillation and the South American Summer Monsoon; Baker and Fritz, 2015) and by apparent teleconnections with longer-range climatic drivers such as Northern hemisphere Heinrich events (Kanner et al., 2012) or Antarctic polar front migration (Moreno et al., 2009).

In the subtropical Andes, easterly systems influenced by the north and central Atlantic in the tropics give way to westerly systems related to the Southern Westerly Winds. The transition region is a zone of persistent aridity known as the Arid Diagonal (De Martonne, 1934). The western cordillera of the Andes in northern Chile crosses the Arid Diagonal between $18^{\circ} \mathrm{S}$ and $27^{\circ} \mathrm{S}$. Between Nevado Sajama (18.1 $\left.1^{\circ} \mathrm{S}\right)$ and Cerro Tapado $\left(30.2^{\circ} \mathrm{S}\right)$ there are no large extant glaciers (Cassassa et al., 2007), but glacial deposits can be mapped as far south as $\sim 24^{\circ} \mathrm{S}$ on the north side of the Arid Diagonal, and likewise as far north as $27^{\circ} \mathrm{S}$ on the south side (Jenny et al., 1996). A few small rock glaciers and permanent snowfields exist on very high peaks throughout the Arid Diagonal. It is not clear whether past glaciers in the Chilean arid diagonal region should have responded similarly to glaciers more directly affected by northeasterly or southwesterly climate features.

Understanding the timing of peak glaciation and deglaciation across this region is one approach to determining the relative influence of the subtropical easterly and mid latitude westerly moisture sources, and their importance relative to radiation and temperature changes over the last global glacial cycle. However, compared to the outer tropical Altiplano and mountains of Peru and Bolivia, and mid-latitudes of Chile and Argentina, there is a paucity of numerical age constraints on these deposits. This is due 
in part to the aridity, which means that organic material suitable for radiocarbon dating is scarce in glacial deposits, and in part to the dominance of intermediate volcanic rock, which limits the utility of the well-constrained ${ }^{10} \mathrm{Be}$ cosmogenic method. In the last few years, the refinement of ${ }^{36} \mathrm{Cl}$ and ${ }^{3} \mathrm{He}$ cosmogenic dating has resulted in some progress in the dating of the glacial deposits in the arid Andes and proximal regions.

In this paper, we review several recent records of deglaciation of the western cordillera of the Andes of northern Chile in a climatic context. We also present new cosmogenic datasets developed for previously undated valley moraines at two sites near $22^{\circ} \mathrm{S}$, and refine a previously presented chronology of the Chajnantor ice cap, which was present at least until early in the global last glacial maximum (LGM) at $23^{\circ} \mathrm{S}$ (Ward et al., 2015). Our focus is a review of available glacial records and data with the aim of understanding the longitudinal pattern in timing of deglaciation over the last global glacial cycle.

\section{Study Area}

\subsection{Geographical setting}

Here we focus on the latest glaciation of the western cordillera of the Andes in northern Chile. This region spans the southwest Altiplano and Puna Plateau regions, which are dominated by high plateau landscapes with typical elevations of 4000-5000 m. Large volcanic complexes of ignimbrite shields, dacite domes, and stratovolcano edifices reach elevations above $6000 \mathrm{~m}$ (e.g., Ramírez and Gardeweg, 1982). The west flank of the Andes here is steep, rising to Altiplanic elevations from the $2000-3000 \mathrm{~m}$ central depression of northern Chile over tens of $\mathrm{km}$ distance. The western cordillera lies $\sim 130 \mathrm{~km}$ inland from the Pacific Ocean near the north and south ends of the study region, and up to $300 \mathrm{~km}$ in the central latitudes. It is separated from the eastern lowlands by $300-500 \mathrm{~km}$, again with the largest distance in the central latitudes of $\sim 21-24^{\circ} \mathrm{S}$.

\subsection{Modern regional climate}

The overall aridity of the Altiplano and subtropical Andes is maintained primarily by the large-scale subtropical downwelling and cold oceanic upwelling along the west coast of South America related to the Humboldt Current (e.g., Hartley, 2003). The basic climatology of the region is also modulated by the El Niño/Southern Oscillation (ENSO), which induces circulation anomalies over South America and is associated with regionally heterogeneous precipitation anomalies (e.g., Vuille, 1999; Garreaud and Aceituno, 2001), and by the South American Summer Monsoon (SASM), which promotes heavy rainfall in the central Amazon Basin (e.g. Cook and Vizy, 2006). An upper-level high-pressure system called the "Bolivian High" appears over the subtropical Andes centered around $19^{\circ} \mathrm{S}, 60^{\circ} \mathrm{W}$ (Lenters and Cook, 1997) in response to latent heating associated with the monsoon. The positioning of the Bolivian High modulates upper-level easterly winds on inter- and intra-annual timescales (Vuille et al., 1998; Garreaud and Aceituno, 2001), affecting moisture transport from the east into the Altiplano and arid Andes (Garreaud, 2000). 
The modern mean annual temperatures at the previously glaciated elevations of the study area $\left(>4000 \mathrm{~m}\right.$ ) range from 4 to $-4{ }^{\circ} \mathrm{C}$ (Grenon, 2007; Kull and Grosjean, 2000). Upper elevations of the Puna Plateau and surrounding area receive between 200 and $350 \mathrm{~mm} / \mathrm{yr}$ of water-equivalent precipitation (Grosjean et al., 2001), with high interannual variability (e.g., Garreaud and Aceituno, 2001; Houston, 2006). Much of this precipitation falls during austral summer (Garreaud et al., 2003) and is derived from moist air transported from the east, arriving from the tropical Atlantic via the Amazon Basin. This moisture promotes summer rain and snow and occasional damaging floods (Mather and Hartley, 2005; Houston, 2006). At the surface of the Altiplano, midday solar radiation ranges from 600 to $1100 \mathrm{~W} / \mathrm{m}^{2}$ (Garreaud et al., 2003). The region's very low humidity, high winds, and high insolation result in high rates of sublimation; field studies indicate 2-4 mm/day water equivalent at Cerro Tapado (Stichler et al., 2001; Kull et al., 2002). In this setting, melting has a negligible impact on mass balance, as meltwater quickly refreezes in the firn: temperatures at depths below $\sim 10 \mathrm{~cm}$ during the Cerro Tapado study never exceeded $0^{\circ}$ and the daytime air temperature was $\sim 3^{\circ}$ during the austral summer period of 11-16 February, 1999 (Stichler et al., 2001).

\subsection{Lacustrine highstands of the Altiplano}

Given how dry it is in the region, many have assumed that glaciers are effectively moisture proxies, and their timing has been assumed to correspond to the highstands of Altiplanic lakes. The most important of these was Lake Tauca, which spread up to $60,000 \mathrm{~km}^{2}$ across the modern day Poopo Basin, the Salar de Uyuuni, and the Salar de Coipasa in the Bolivian Altiplano (Placzek et al., 2013; Fig. 1). The most extensive highstand of Lake Tauca occurred 18.1-14.1 ka; the previous deepest phase in these basins (Lake Ouki) likely dates to 120-98 ka (Placzek et al., 2013). These highstands are attributed to significant changes in hydroclimate, particularly increased moisture delivery. Minor highstands in the Altiplano occurred ca. 80-95 ka, $46 \mathrm{ka}, 20-24 \mathrm{ka}$, and 11-13 ka, and may be attributed to reduced evaporation and temperature. The 20-24 ka and $\sim 46 \mathrm{ka}$ highstands of Altiplanic lakes correspond with highstands in the Salar de Atacama (Fig. 1; Bobst et al., 2001).

However well-constrained the Tauca history is, it does not universally correspond to lacustrine records farther south in the Altiplano-Puna region. McGlue et al. (2013) presents a record of sedimentation, dated using radiocarbon, from Pozuelos Basin, northwestern Argentina $\left(22.5^{\circ} \mathrm{S}\right)$. Sedimentology from 6 cores indicates that this lake was profundal 43-32 Cal ka, transitioning to saline from $25 \mathrm{ka}-18 \mathrm{ka}$, and drying to a playa by the late Holocene. There is little evidence here of a major transgression during the Tauca wet phase of the Altiplanic lakes, indicating a regional spatial transition in hydroclimate between $\sim 20^{\circ} \mathrm{S}$ and $\sim 22^{\circ} \mathrm{S}$.

\subsection{Glaciological context}

According to the classification of Sagredo et al. (2014), the area spans the transition between extant glaciers of the dry outer tropics (western cordilleras of Peru and Bolivia to about $18.5^{\circ} \mathrm{S}$ ) and those of the subtropics (western cordillera of Chile south of $26^{\circ} \mathrm{S}$ ). The dry outer tropical glaciers receive most of their moisture during DJFM - "Bolivian 


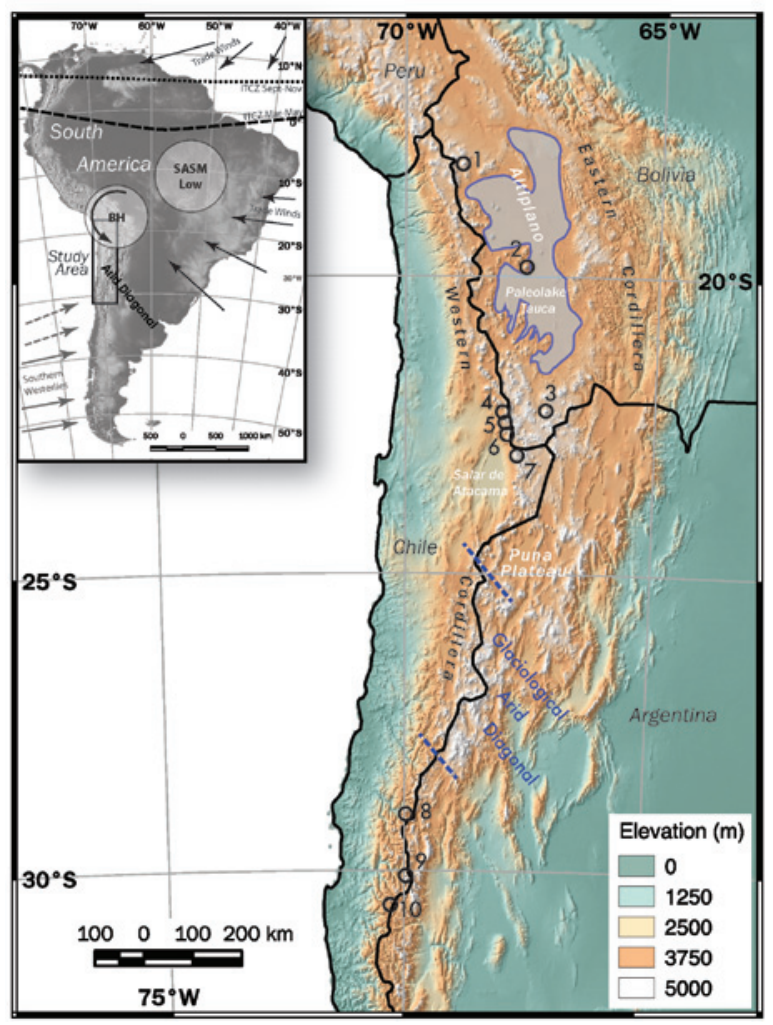

Figure 1. Inset: Major climate features and location of the study area in the western cordillera of the Andes. ITCZ: Intertropical Convergence Zone; BH: Bolivian High; SASM: South American Summer Monsoon. Main map shows locations of dated glacial deposits as in Table 1. 1: Nevado Sajama; 2: Cerro Tunupa; 3: Cerro Uturuncu; 4: El Tatio; 5: Cerro La Torta; 6: Sairecabur; 7: Chajnantor Plateau; 8: Encierro Valley; 9: Cerro Tapado; 10: Cordon de Doña Rosa. Between $18.5^{\circ} \mathrm{S}$ and $27^{\circ} \mathrm{S}$ in the western cordillera, no modern glaciers exist, and within the zone labeled "glaciological arid diagonal", there is no clear evidence for past glaciation.

Winter", and are moderately sensitive to both temperature and precipitation changes. On the other hand, subtropical glaciers receive more moisture during JJA than during the remainder of the year, and are very precipitation-limited. The region between is currently fully deglaciated save for a handful of rock glaciers, and corresponds the climatic region known as the "Arid Diagonal" (De Martonne, 1934). The Arid Diagonal is defined by different workers based on different criteria; here, we use a glaciological definition, meaning the latitude band where there are no present glaciers. Within the Arid Diagonal, glacial deposits can be traced as far south as $24^{\circ} \mathrm{S}$, but there is no further clear evidence for glaciation between there and $27^{\circ} \mathrm{S}$ in the western cordillera.

Jenny et al. (1996) used aerial and satellite images to map moraines between $17^{\circ} \mathrm{S}$ and $29^{\circ} \mathrm{S}$ along the western cordillera of the Andes in Chile, and described three moraine stages: a more degraded, distal set of moraines, and two more proximal and better-preserved stages. These stages were not directly dated, but based on morphology and published proxy 
moisture data, were assigned tentative ages of $\sim 130+\mathrm{ka}, \sim 20 \mathrm{ka}$, and 17-15 ka, coinciding with documented highstands of Altiplanic lakes. Based on this mapping, Amman et al. (2001) calculated snowlines for the most prominent set of moraines based on the AAR method. They show a rapid rise from $\sim 4600 \mathrm{~m}$ to $>5000 \mathrm{~m}$ between $22^{\circ} \mathrm{S}$ and $24^{\circ} \mathrm{S}$ to above the topography in the "glaciological arid diagonal" in which there is no evidence for glaciation, and a rapid decline from $5300 \mathrm{~m}$ to $\sim 4000 \mathrm{~m}$ moving south from $27^{\circ} \mathrm{S}$ through $29^{\circ} \mathrm{S}$. They note however, that the lack of direct dating precludes assigning their calculated ELA trends to the same time frames on either side of the Arid Diagonal.

Interpreting climatic history from the glacial deposits in the western cordillera is complicated by the unusual climate setting. While moisture is regarded as the limiting factor for glaciation (e.g., Kull and Grosjean, 2000; Sagredo et al., 2014), and so glacial stages have been assumed to coincide with documented wet periods, it was likely also $6-8^{\circ} \mathrm{C}$ colder in this area during LGM, and shortwave radiation has changed significantly over the last glacial cycle as well (Kull and Grosjean, 1998). Moreover, the dating of these moraines, recently enabled by advances in cosmogenic dating, indicate a history for glaciation that may be more locally variable and complex than the three-regional-stages model proposed by Jenny et al. (1996). We review these records in more detail below.

\section{Methods}

\subsection{Methods - Literature Review}

We examine seven published studies describing exposure ages from moraines and glaciated bedrock spanning the glaciological Arid Diagonal: Nevado Sajama in the north to Cordón de Doña Rosa in the south, including Co. Tapado (Table 1). We also describe cosmogenic ${ }^{36} \mathrm{Cl}$ exposure ages from two new, previously undated sets of moraines in the deglaciated region near $22^{\circ} \mathrm{S}$.

While all records reviewed here are based on cosmogenic exposure methods, the specific techniques used in each depended on the available rock for dating and the study design. Recent progress in reconciling varying production rate scaling schemes gives us some confidence that these ages may be compared directly (e.g., Lifton et al., 2014; Blard et al., 2013a; Kelly et al., 2015; see discussion in Ward et al., 2015).

Ages were recalculated using the community standard CRONUSCalc online calculator (Marrero et al., 2016a; http://web1.ittc.ku.edu:8888/2.0/; v.2.0). All ages were recalculated assuming zero erosion. At four sites, we have rescaled cosmogenic ages as reported in the original studies to be comparable to the other sites (Table 2). For ${ }^{10} \mathrm{Be}$, the time-varying LalStone scheme (Balco, 2008; Lifton et al., 2014) was used with a baseline production rate as cross-calibrated with ${ }^{3} \mathrm{He}$ and ${ }^{14} \mathrm{C}$ at the Cerro Tunupa site of Blard et al. (2013a); therefore, the ages from this site and the ${ }^{3} \mathrm{He}$ dataset at Cerro Uturuncu (Blard et al., 2014) were not rescaled. The ${ }^{10} \mathrm{Be}$ ages for sites 5 and 7 were originally published using these scaling schema (Ward et al., 2015). The ${ }^{10}$ Be ages from sites 8 and 10 (Zech et al., 2006, 2007) were rescaled because the authors originally used an older scaling routine that is now known to have a low bias at low latitudes and high altitudes (Lifton et al., 2014). Calculated exposure ages increased due to rescaling by $45-51 \%$ at site 8 and by $25-51 \%$ at site 10 (Table 2). 
Table 1. Locations of published records reviewed here.

\begin{tabular}{|c|c|c|c|c|c|c|}
\hline $\begin{array}{l}\text { Map } \\
\text { ID }\end{array}$ & Nuclide & Location & $\begin{array}{c}\text { Mean } \\
\text { Latitude } \\
(\operatorname{deg} \mathrm{S})\end{array}$ & $\begin{array}{c}\text { Mean } \\
\text { Longitude } \\
\text { (deg W) }\end{array}$ & $\begin{array}{l}\text { Terminus } \\
\text { Elevation* } \\
(\mathrm{m})\end{array}$ & Reference \\
\hline 1 & ${ }^{36} \mathrm{Cl}^{\dagger}$ & Nevado Sajama, Bolivia & 18.11 & 68.88 & 4300 & Smith et al., 2009 \\
\hline 2 & ${ }^{3} \mathrm{He} /{ }^{10} \mathrm{Be}$ & Cerro Tunupa, Bolivia & 19.87 & 67.61 & 3900 & Blard et al., 2009; 2013b \\
\hline 3 & ${ }^{3} \mathrm{He}$ & Cerro Uturuncu, Bolivia & 22.30 & 67.20 & 4700 & Blard et al., 2014 \\
\hline 4 & ${ }^{36} \mathrm{Cl}$ & Cordillera del Tatio, Chile & 22.30 & 67.98 & 4100 & This study \\
\hline 5 & ${ }^{10} \mathrm{Be}$ & Cerro La Torta, Chile & 22.43 & 67.99 & 4500 & Ward et al., 2015 \\
\hline 6 & ${ }^{36} \mathrm{Cl}$ & Sairecabur, Chile & 22.71 & 67.94 & 4600 & This study \\
\hline 7 & ${ }^{10} \mathrm{Be}^{36} \mathrm{Cl}^{\dagger}$ & Chajnantor Plateau, Chile & 22.91 & 67.80 & 4400 & Ward et al., 2015 \\
\hline 8 & ${ }^{10} \mathrm{Be}^{\dagger}$ & Encierro Valley, Chile & 29.10 & 69.90 & 3600 & Zech et al., 2006 \\
\hline 9 & ${ }^{36} \mathrm{Cl}$ & Cerro Tapado, Chile & 30.14 & 69.93 & 4100 & Sagredo et al., 2016 \\
\hline 10 & ${ }^{10} \mathrm{Be}^{\dagger}$ & Cordón de Doña Rosa, Chile & 30.71 & 70.40 & 3100 & Zech et al., 2007 \\
\hline
\end{tabular}

* Most distal prominent moraines of dated glacial valley(s), to nearest $100 \mathrm{~m}$.

$\dagger$ Ages were rescaled for this review - see Table 2.

Table 2. Results of age rescaling by site / publication

Smith et al. (2009) ${ }^{36} \mathrm{Cl}$

\begin{tabular}{cccccc}
\hline Sample & Age ka (published) & Uncertainty & Age ka (rescaled) & Uncertainty & \% Change* \\
\hline BV-06-01 & 9.4 & 0.2 & 19.4 & 2.6 & 106.3829787 \\
BV-06-02 & 7.5 & 0.2 & 12.3 & 1.3 & 64 \\
BV-06-03 & 14.1 & 0.3 & 21.9 & 1.9 & 55.31914894 \\
BV-06-08 & 15.1 & 0.4 & 23.1 & 2.1 & 52.98013245 \\
BV-06-09 & 9 & 0.3 & 15.2 & 1.5 & 68.88888889 \\
BV-06-13 & 11.3 & 0.3 & 17.6 & 1.5 & 55.75221239 \\
BV-06-14 & 9.7 & 0.2 & 17.9 & 2.3 & 84.53608247 \\
BV-06-34 & 8.4 & 0.2 & 11.9 & 1.1 & 41.66666667 \\
BV-06-35 & 7.3 & 0.2 & 11.3 & 1.2 & 54.79452055 \\
BV-06-36 & 12.8 & 0.4 & 19.9 & 1.1 & 55.46875 \\
BV-06-28 & 4.9 & 0.1 & 6.1 & 0.28 & 24.48979592 \\
BV-06-29 & 2.2 & 0.1 & 4.03 & 0.67 & 83.18181818 \\
BV-06-30 & 3.3 & 0.1 & 5.16 & 0.46 & 56.36363636 \\
BV-06-31 & 6.7 & 0.2 & 10 & 1 & 49.25373134 \\
BV-06-25 & 6.2 & 0.2 & 6.81 & 0.88 & 9.838709677 \\
BV-06-26 & 5.9 & 0.2 & 8.04 & 0.93 & 36.27118644 \\
BV-06-27 & 6.8 & 0.2 & 5.62 & 0.73 & -17.35294118 \\
BV-06-10 & 3.2 & 0.1 & 6.22 & 0.42 & 94.375 \\
BV-06-11 & 4.6 & 0.1 & 4.83 & 0.61 & 5 \\
BV-06-12 & 2.5 & 0.1 & 4.81 & 0.57 & 92.4 \\
BV-06-17 & 4.3 & 0.2 & 5.57 & 0.41 & 29.53488372 \\
BV-06-18 & 2.7 & 0.1 & 3.76 & 0.63 & 39.25925926 \\
BV-06-19 & 2.7 & 0.1 & 8.5 & 1.5 & 214.8148148 \\
BV-06-32 & 4 & 0.1 & 8.2 & 1.2 & 105 \\
\hline & & & & & \\
\hline
\end{tabular}




\begin{tabular}{cccccc}
\hline BV-06-33 & 2.3 & 0.1 & 8.8 & 1.3 & 282.6086957 \\
BV-06-23 & 0.3 & 0 & 0 & 0 & -100 \\
BV-06-24 & 0.2 & 0 & 0 & 0 & -100 \\
BV-06-04 & 8.5 & 0.2 & 11.25 & 0.91 & 32.35294118 \\
BV-06-05 & 8.1 & 0.4 & 11.1 & 1.1 & 37.03703704 \\
BV-06-06 & 27.8 & 0.8 & 44.7 & 5.8 & 60.79136691 \\
BV-06-07 & 20.3 & 0.5 & 32.9 & 3.6 & 62.06896552 \\
BV-06-15 & 8.4 & 0.2 & 11.62 & 0.92 & 38.33333333 \\
BV-06-16 & 7.9 & 0.2 & 10.9 & 1.1 & 37.97468354 \\
BV-06-20 & 13.4 & 0.3 & 18.3 & 1.2 & 36.56716418 \\
BV-06-21 & 10.2 & 0.3 & 14.8 & 1.1 & 45.09803922 \\
BV-06-22 & 11.3 & 0.4 & 14.79 & 0.95 & 30.88495575 \\
\hline & & & & MEAN & $\mathbf{5 3 . 4 9 8 2 3 4 9 4}$ \\
\hline
\end{tabular}

Ward et al. (2015) ${ }^{36} \mathrm{Cl}$ - Site 7 - Chajnantor Plateau

\begin{tabular}{cccccc}
\hline Sample & Age ka (published) & Uncertainty & Age ka (rescaled) & Uncertainty & \% Change \\
\hline CHAJ-12-03 & 38.4 & 5.2 & 60.5 & 8.8 & 57.55208333 \\
CHAJ-12-04 & 26.4 & 4.4 & 31.7 & 4.6 & 20.07575758 \\
CHAJ-12-06 & 177 & 38 & 186 & 37 & 5.084745763 \\
CHAJ-12-08 & 49 & 13.1 & 55 & 17 & 12.24489796 \\
CHAJ-12-11 & 25.7 & 1.7 & 47.9 & 5.3 & 86.38132296 \\
CHAJ-12-14 & 122 & 14.3 & 119 & 26 & -2.459016393 \\
CHAJ-12-15 & 30.1 & 2.8 & 53.9 & 7.1 & 79.06976744 \\
CHAJ-12-18 & 40.8 & 3.5 & 67.6 & 7.8 & 65.68627451 \\
CHAJ-12-19 & 11.2 & 1.3 & 18.8 & 1.9 & 67.85714286 \\
CHAJ-12-20 & 19.1 & 1.6 & 26.7 & 2.8 & 39.79057592 \\
CHAJ-12-21 & 14.7 & 1.1 & 28.4 & 2.7 & 93.19727891 \\
CHAJ-M2 & 58.6 & 16.4 & 62 & 17 & 5.802047782 \\
\hline
\end{tabular}

Zech et al. (2006) ${ }^{10} \mathrm{Be}$ - Site 8 - Encierro Valley

\begin{tabular}{cccccc}
\hline Sample & Age ka (published) & Uncertainty & Age ka (rescaled) & Uncertainty & \% Change \\
\hline EE11 & 11.6 & 0.5 & 17.485 & 1.286 & 50.73275862 \\
EE12 & 11.3 & 0.4 & 17.128 & 1.223 & 51.57522124 \\
EE22 & 10.4 & 0.4 & 15.905 & 1.135 & 52.93269231 \\
EE24 & 10.9 & 0.5 & 16.571 & 1.228 & 52.02752294 \\
EE33 & 10.9 & 0.7 & 16.65 & 1.415 & 52.75229358 \\
EE34 & 14 & 0.6 & 20.988 & 1.633 & 49.91428571 \\
EE42 & 12.3 & 0.5 & 18.385 & 1.374 & 49.47154472 \\
EE51 & 13.7 & 0.5 & 20.358 & 1.51 & 48.59854015 \\
EE62 & 13.1 & 0.7 & 19.157 & 1.538 & 46.23664122 \\
EE63 & 9.3 & 0.4 & 13.843 & 1.017 & 48.84946237 \\
EE71 & 24.1 & 0.9 & 35.027 & 2.588 & 45.34024896 \\
\hline & & & & MEAN & $\mathbf{4 9 . 8 5 7 3 8 2 8 9}$ \\
\hline
\end{tabular}


Zech et al. (2007) ${ }^{10} \mathrm{Be}$ - Site 10 - Cordón de Doña Rosa

\begin{tabular}{cccccc}
\hline Sample & Age ka (published) & Uncertainty & Age ka (rescaled) & Uncertainty & \% Change \\
\hline DR11 & 11.6 & 0.5 & 17.344 & 1.247 & 49.51724138 \\
DR13 & 12.8 & 0.5 & 18.976 & 1.375 & 48.25 \\
DR21 & 17.5 & 0.6 & 25.638 & 1.861 & 46.50285714 \\
DR31 & 11.7 & 0.5 & 17.31 & 1.264 & 47.94871795 \\
DR32 & 14.7 & 0.5 & 21.536 & 1.539 & 46.50340136 \\
DR33 & 13.2 & 0.4 & 19.33 & 1.324 & 46.43939394 \\
DR41 & 11.7 & 0.6 & 17.297 & 1.4 & 47.83760684 \\
DR42 & 12.5 & 0.5 & 18.287 & 1.356 & 46.296 \\
DR43 & 12.1 & 0.5 & 17.786 & 1.289 & 46.99173554 \\
DR51 & 98.1 & 2.5 & 148.433 & 10.43 & 51.30784913 \\
DR52 & 32.1 & 0.8 & 45.488 & 3.115 & 41.70716511 \\
DR61 & 34.4 & 1 & 49.304 & 3.522 & 43.3255814 \\
DR62 & 31.1 & 0.9 & 43.733 & 3.054 & 40.62057878 \\
DR71 & 29.8 & 1.4 & 41.874 & 3.494 & 40.51677852 \\
DR72 & 15.6 & 0.6 & 22.142 & 1.643 & 41.93589744 \\
DR73 & 25.1 & 0.9 & 35.52 & 2.625 & 41.51394422 \\
DR81 & 31.7 & 1.2 & 42.099 & 3.164 & 32.8044164 \\
DR82 & 43.1 & 1.6 & 62.118 & 4.693 & 44.12529002 \\
DR91 & 27.2 & 1 & 35.061 & 2.651 & 28.90073529 \\
DR92 & 26.6 & 0.7 & 34.312 & 2.391 & 28.9924812 \\
DR101 & 16.8 & 1.6 & 21.085 & 2.571 & 25.50595238 \\
DR102 & 24.2 & 0.9 & 30.416 & 2.297 & 25.68595041 \\
\hline & & & & MEAN & $\mathbf{4 1 . 5 1 0 4 3 5 2}$ \\
\hline & & & & & \\
\hline
\end{tabular}

For ${ }^{36} \mathrm{Cl}$, we employ the newer time-varying Lifton-Sato-Dunai (LSD) scheme (Lifton et al., 2014), which for this region gives both ${ }^{36} \mathrm{Cl}$ and ${ }^{10} \mathrm{Be}$ ages within $\sim 1-2 \%$ of the time-varying Lal-Stone scheme, i.e., within analytical error of the scheme used above for ${ }^{10} \mathrm{Be}$ (e.g., Sagredo et al., 2016). We also use this scaling for the new results presented here (sites 4, 6, and the new ${ }^{36} \mathrm{Cl}$ samples from site 7). Sagredo et al. (2016) also presented their ages for site 9 using this scaling. Therefore, only the published ${ }^{36} \mathrm{Cl}$ ages from sites 1 and 7 needed to be rescaled. Similarly to the ${ }^{10} \mathrm{Be}$, and for similar reasons, rescaling resulted in an average increase in calculated ${ }^{36} \mathrm{Cl}$ exposure ages of 53\% for site 1 and $44 \%$ for site 7. Inter-sample variability in rescaling was much higher for ${ }^{36} \mathrm{Cl}$, however; some ages decreased by tens of percent or more, and a few ages increased by $>200 \%$ (Table 2). This variability is likely caused by variations in the geochemistry between samples.

Generally, $1-\sigma$ analytical plus scaling uncertainties are on the order of 10-15\% for the data presented here, and the geologic uncertainty (e.g., due to inherited nuclide inventories and postdepositional erosion) inherent in cosmogenic dating of moraines is likely much larger than that. We discuss those geological uncertainties as necessary in the context of each record, below. Nonetheless, it means that the precision of determining ages of specific landforms in this region, based on these data, is at best $\pm 2-3 \mathrm{ka}$. 


\subsection{Methods -Cosmogenic Dating}

Samples were collected for cosmogenic ${ }^{36} \mathrm{Cl}$ dating (Gosse and Phillips, 2001; Marrero et al., 2016b) from prominent boulders at the crests of moraine ridges, using hammer and chisel (Fig. 2). Many moraine boulders were in poor condition and had to be rejected for sampling, limiting the density of boulder samples on each moraine. Measurements of the skyline indicate negligible amounts of topographic shielding at all sample sites, and the arid, windy environment reduces the potential for significant snow shielding on prominent boulders. Generally, boulders with intact, horizontal upper surfaces were samples, and sample thickness limited to $<=5 \mathrm{~cm}$; samples thicker than this were cut to this thickness in the lab before processing. Where necessary, surface inclination measurements were made and computed as part of the shielding factor for each sample; these corrections were generally negligible.

Chemical preparation and sample dissolution for ${ }^{36} \mathrm{Cl}$ was carried out at the University of Cincinnati and followed the methods of Stone et al. (1996). Methods were modified to accelerate the dissolution process (J. Radler, Purdue University, personal

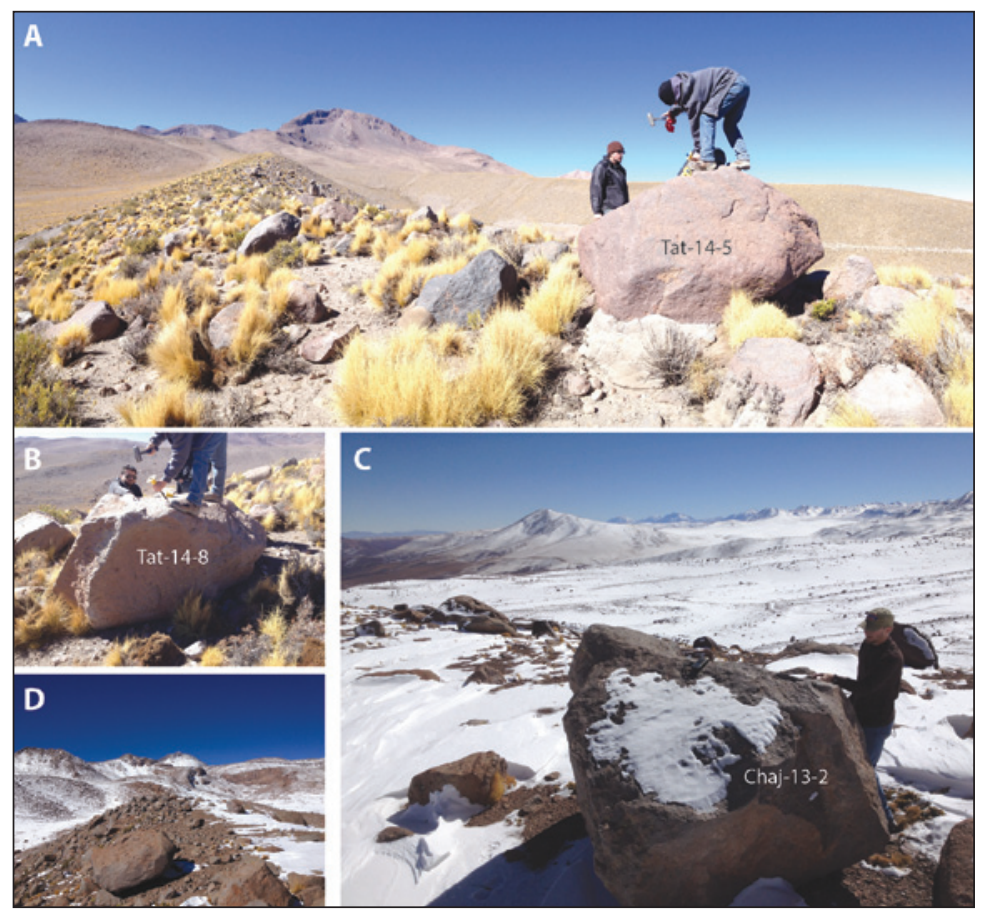

Figure 2. Examples of moraines and boulders sampled at El Tatio and Sairecabur. A: View to east and upvalley from sample Tat-14-5, right-lateral moraine, El Tatio (Fig. 4). B. View to north of sample Tat-14-8. C. View from sample Chaj-13-2 on the left-lateral moraine at the Sairecabur site, looking to the north diagonally across and downvalley (Fig. 5). Note the moraine ridges in the middle distance. D. View east and upvalley on the right-lateral moraine near sample Chaj-

13-5 (not in frame) at Sairecabur. 


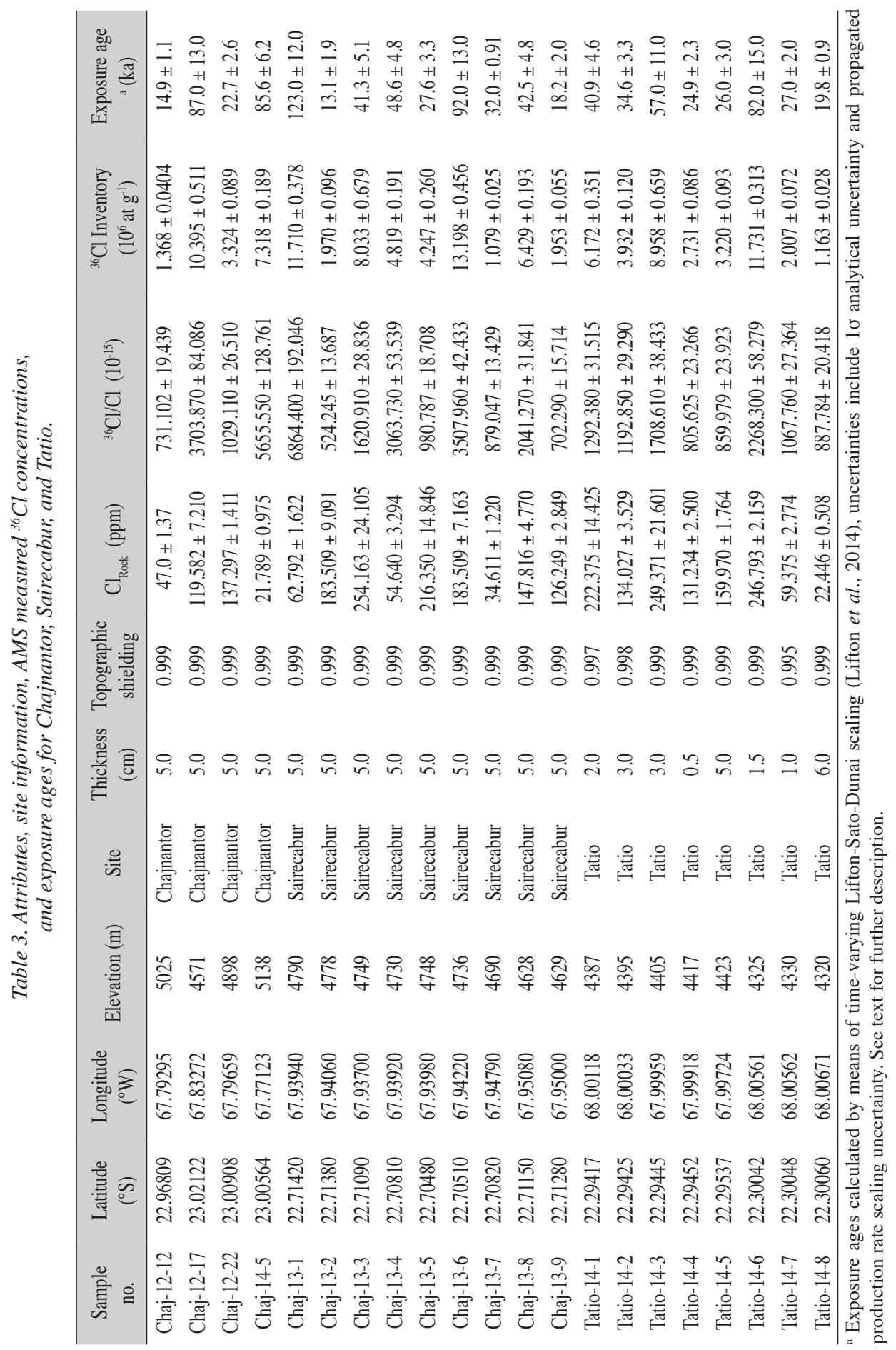




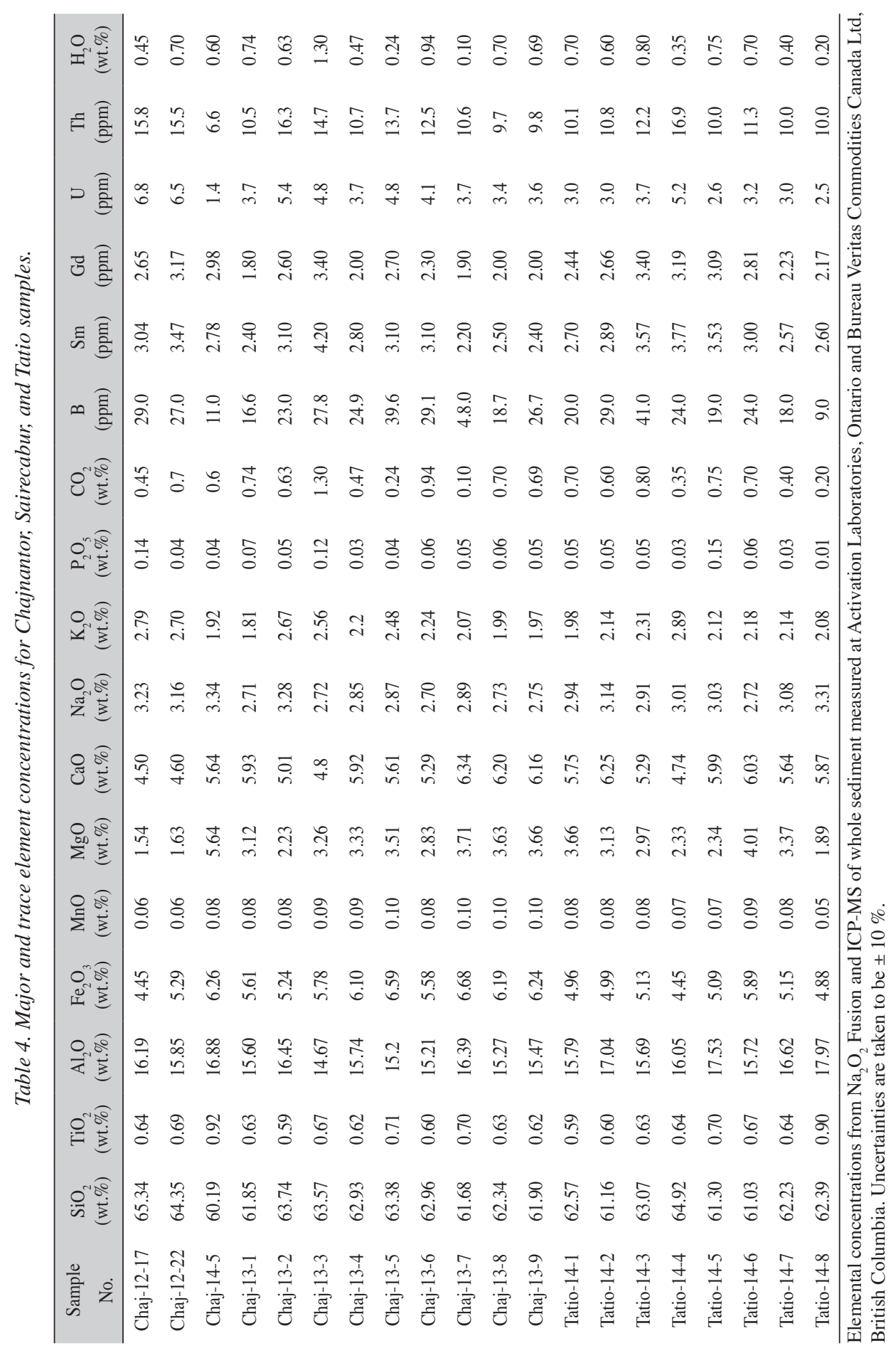


communication). Samples were crushed and sieved to the $125-250 \mu \mathrm{m}$ fraction, and $100 \mathrm{~g}$ was leached overnight in dilute TMG (trace metal grade) $\mathrm{HNO}_{3}$ and subsequently rinsed to remove the meteoric ${ }^{36} \mathrm{Cl}$ component. After drying, a $10 \mathrm{~g}$ aliquot was reserved for major and trace element geochemistry while $30 \mathrm{~g}$ of the leached material was spiked with $\sim 1.0 \mathrm{mg}$ of enriched ${ }^{35} \mathrm{Cl}$ carrier and dissolved in concentrated TMG HF and TMG $\mathrm{HNO}_{3}$. Upon complete dissolution, $\mathrm{AgCl}$ was precipitated through the addition of $\mathrm{AgNO}_{3}$. The precipitate was collected, redissolved through the addition of $\mathrm{NH}_{4} \mathrm{OH}$, and eluted through anion exchange columns to remove interfering ions. Once eluted, the $\mathrm{AgCl}$ was re-precipitated through the addition of $\mathrm{AgNO}_{3}$ and $\mathrm{HNO}_{3}$. The $\mathrm{AgCl}$ precipitate was dried and loaded into $\mathrm{Cu}$ cathode holders for AMS analysis at Purdue Rare Isotope Measurement (PRIME) Lab. Major and trace element geochemistry was analyzed by $\mathrm{Na}_{2} \mathrm{O}_{2}$ fusion and ICP-MS at Activation Laboratories Ltd. in Ontario, Canada, and at Bureau Veritas Commodities Canada Ltd., British Columbia, Canada. As with the rescaled ages from the literature, the ${ }^{36} \mathrm{Cl}$ ages presented here were calculated based on the LSD scaling scheme using the CRONUSCalc online calculator (Marrero et al., 2016a). Tables 3 and 4 list the details of sample locations, geochemistry, and other relevant data.

\subsection{Methods - Age Screening and Stratigraphic Interpretation}

Ages presented here (both from the literature and our own) were interpreted in a stratigraphic context. In the manuscripts we review, different authors used different interpretive strategies. For consistency, we reinterpret all datasets based on the rescaled ages and moraine stratigraphy. In most cases, our interpretation agrees with those of the original manuscript.

In this region, relatively few individual landforms or stages have a sufficient number of dates to apply a formal statistical method. Where multiple dates are present on the same landform or stage, we assign landform age based on the range of ages that overlap within uncertainty, and deprioritize ages that do not overlap within the uncertainty range. Exceptions to the above are noted where relevant, for example, cases where insufficient data are available. Finally, regional context is considered in cases where the local stratigraphic interpretation is unclear; nearby records with similar stratigraphy are used as a guide to understanding the age patterns at a site with little or difficult to interpret data. Glaciers in this region were potentially thin and cold-based, leaving locally-variable deposits that have been overprinted in some cases by ashfall deposits, lahars, landslides, rock glaciers, and periglacial features. We therefore consider site-to-site morphostratigraphic interpretation to be unreliable in this setting, because many features are ambiguous in satellite imagery, and we have not visited each site to make more detailed observations.

\section{Review of existing glacial studies}

\subsection{Nevado Sajama (Smith et al., 2009)}

Nevado Sajama $\left(18.11^{\circ} \mathrm{S}, 68.88^{\circ} \mathrm{W}\right)$, a stratovolcano located along the eastern flank of the Western Cordillera in Bolivia, is one of the southernmost peaks in the Western 
Cordillera with modern glaciers (Smith et al., 2009). In the Patokho, Huaqui Jihuata, and Phajokhoni valleys (listed from north to south) on the western flank of Nevado Sajama, Smith et al. (2009) identified two distinct lateral-terminal moraine groups: (1) tall $60-80 \mathrm{~m}$ high lateral moraines that enclose the valleys, and (2) short 1-4 m high moraines that inset and overlie the taller moraines (Smith et al., 2009). They also mapped four ground moraine deposits. Ground Moraine 1 is associated with the tall lateral moraines $(4350 \mathrm{~m}$ to $4635 \mathrm{~m}$ minimum elevation), and is defined by boulder-rich, hummocky ridges $\sim 3 \mathrm{~m}$ high. Ground Moraine 2 (4585 to $4925 \mathrm{~m}$ minimum elevation) overprints the up-valley portion of Ground Moraine 1. The deposit is bounded by 2-4 m high moraines and is also interpreted to consist of englacial and supraglacial debris (Smith et al., 2009). Ground Moraine 3 (4745 to $5000 \mathrm{~m}$ minimum elevation) is a thicker ( $>100 \mathrm{~m}$ thick) deposit that overprints Ground Moraine 2 in Huaqui Jihuata and exhibits a steep down valley slope with an inset hummocky surface. Owing to the morphology and lack of lateral moraines, Smith et al. (2009) interpreted Ground Moraine 3 to represent a fossil rock glacier deposit. In recent Google Earth imagery, active rock glaciers are apparent farther up the slope from this deposit, and its upper extent is partly buried in outwash fan deposits originating from the modern rock glacier margins. The Plateau Ground Moraine identified by Smith et al. (2009) occurs on high-elevation low-angle plateaus that surround Sajama, rather than within the glacial valleys. The unit consists of hummocky terrain and lacks bounding moraine ridges, and is interpreted to be deposited by cold-based ice spilling over the valley margins; we consider this interpretation to be speculative.

Huaqui Jihuata and Patokho valleys exhibit terminal moraine/fan complexes associated with Ground Moraine 1 that were dated by Smith et al. (2009) using ${ }^{36} \mathrm{Cl}$. At the terminus of Huaqui Jihuata, three samples from a narrow moraine ridge yield 11.3 $\pm 1.2,11.9 \pm 1.1$, and $19.9 \pm 1.1 \mathrm{ka}$. Five ages from the outermost dated moraine at Patokho valley terminus were $12.3 \pm 1.3,15.2 \pm 1.5,19.4 \pm 2.6,21.9 \pm 1.9$, and $23.1 \pm 2.1 \mathrm{ka}$. A small loop moraine crosscutting the outer moraine on the southern margin of the terminal area yielded 2 identical ages of $17.6 \pm 1.5$ and $17.9 \pm 2.3$. In stratigraphic context, we interpret that the terminal complex was occupied at 19-23 ka, with a minor moraine-forming event at 17-18 ka, and deglaciated possibly as late as $11 \mathrm{ka}$ in Huaqui Jihuata. The younger ages here may also reflect incision of the moraine/fan complexes during deglaciation.

Nine samples were dated from glaciated bedrock upvalley from the terminal complexes of Huaqui Jihuata and Patokho valleys. Two groups of samples were dated from each valley. In Huaqui Jihuata, two samples from near the thalweg $\sim 2 \mathrm{~km}$ upvalley from terminal complex of yield identical ages of $11.10 \pm 1.1$ and $11.25 \pm 0.91 \mathrm{ka}$. Two samples from a similar position in Patokho valley yield exposure ages of $10.90 \pm 1.1$ and $11.62 \pm 0.92 \mathrm{ka}$.

Two samples from glaciated bedrock along the valley side $500 \mathrm{~m}$ upvalley of the terminus of Huaqui Jihuata return older exposure ages of $32.9 \pm 3.6$ and $44.7 \pm 5.8 \mathrm{ka}$. If this location was ice-covered as late as 11-20 ka, as suggested by the moraine ages, these ages must contain cosmogenic inheritance, and suggest that bedrock erosion in this marginal, distal position was likely limited. Three bedrock exposure ages in Patokho valley $\sim 2.5 \mathrm{~km}$ upvalley and high on the valley side yield exposure ages of $14.79 \pm 0.95,14.8 \pm 1.1$, and $18.3 \pm 1.2 \mathrm{ka}$, and suggest that ice had started to thin to expose this sidewall by $\sim 15 \mathrm{ka}$. 
The Plateau Ground Moraine appears to have been deposited outside of the northern edge of Patokho valley. Three boulder samples from its distal margin date to $5.62 \pm 0.73$, $6.81 \pm 0.88$, and $8.04 \pm 0.93 \mathrm{ka}$. Within the confines of Patokho valley, Ground Moraine 2 overprints the Plateau Ground Moraine. Four boulder samples from its distal portion, 3.5 $\mathrm{km}$ upvalley from the terminal complex, yield exposure ages of $4.03 \pm 0.67,5.16 \pm 0.46$, $6.10 \pm 0.38$, and $10.0 \pm 1.0 \mathrm{ka}$. Similarly, 5 samples from Ground Moraine 3 range from $3.76 \pm 0.63 \mathrm{ka}$ to $6.22 \pm 0.42$, and three other samples cluster between $8.2 \pm 1.2 \mathrm{ka}$ and $8.8 \pm 1.3 \mathrm{ka}$. However their origin and cross-cutting relationships are interpreted, Ground Moraines 2 and 3 and the Plateau Ground Moraine appear to have been emplaced between 4 and $6 \mathrm{ka}$.

Two boulders sampled from the active rock glacier in Phajokhoni valley yield concentrations of ${ }^{36} \mathrm{Cl}$ so low that they calculate as 0 ka ages.

In summary, the rescaled glacial chronology from Nevado Sajama suggests that the main phase of development for Ground Moraine 1 and the terminal complexes was between 17 and $23 \mathrm{ka}$. Glacial retreat was likely underway ca. $15 \mathrm{ka}$, and ice had completely withdrawn from the ice contact slopes along the valleys by $11 \mathrm{ka}$. Minor advances or standstills likely occurred between 4 and $6 \mathrm{ka}$, developing the Plateau Ground Moraine, and Ground Moraine 2 and 3. Subsequent glacial retreat reduced the glacial extent to near the present ice margin (Smith et al., 2009).

\subsection{Cerro Tunupa (Blard et al., 2009, 2013b)}

Evidence of glaciation from Cerro Tunupa $\left(19.87^{\circ} \mathrm{S}, 67.61^{\circ} \mathrm{W}\right)$, adjacent to the Salar de Uyuni basin, suggests multiple stages of glacial occupation (Blard et al. 2009, 2013b). Mapping and ${ }^{3} \mathrm{He}$ surface exposure dating of glacial moraines and associated glaciofluvial fan deltas in Chalcala Valley on the southeast flank of Cerro Tunupa by Blard et al. (2009, 2013b) identified four moraines (M0 through M3) and two fan lobes (Mf1a and Mf1b). An old moraine outlet delineated by M0 (3828 m) is crosscut by M1 $(\sim 4200 \mathrm{~m})$, a sharp-crested lateral moraine that delimits the former glaciated Chalcala valley. Blard et al. (2009) suggest that a distal glaciofluvial fan delta Mf1 ( 3760 m) is associated with the M1 moraine, and stratigraphic relationships therein provide additional temporal constraints on moraine termination. Inset within M1, lateral moraine M2 ( 4250 m) likely resulted from the initial stage of glacial retreat. Elongated moraines M3 (4420 m), situated stratigraphically above striated bedrock, denote a later readvance originating from the glacier cirque (Blard et al., 2009).

Surface exposure ages from boulders on M0 indicate moraine abandonment by $147 \pm$ 7 to $172 \pm 8 \mathrm{ka}$. Four exposure ages on boulders of M1 range between $15.6 \pm 0.9$ and $17.0 \pm 0.9 \mathrm{ka}$. Exposure ages on the Mf1 fan delta yield similar ages, between $15.2 \pm 0.8$ and $18.2 \pm 0.8 \mathrm{ka}$, and support the proposed genetic relationship with the M1 moraine. An additional exposure age of $27.6 \pm 1.3 \mathrm{ka}$ on Mf1 represents a maximum age for the initial glacial advance that led to the deposition of the glaciofluvial fan delta (Blard et al., 2009, 2013b). Moraine M2 is constrained by five exposure ages that range from $14.1 \pm$ 1.0 to $15.4 \pm 0.9 \mathrm{ka}$. Striated bedrock up-valley of the M2 moraine yields two identical exposure ages of $15.1 \pm 0.8 \mathrm{ka}$, while boulders on M3 moraines yield exposure ages 
between $12.0 \pm 0.7$ and $13.7 \pm 0.7 \mathrm{ka}$. The glacial chronology from Chalcala valley on Cerro Tunupa suggests that the main development of the M1 moraine occurred between 17 to $16 \mathrm{ka}$, and the local LGM likely persisted until $15.5 \mathrm{ka}$. Subsequent glacial retreat occurred between 15.5 and $14.5 \mathrm{ka}$, with a minor, short-lived advance ca. $13 \mathrm{ka}$.

\subsection{Cerro Uturuncu (Blard et al., 2014)}

Uturuncu volcano is located within the southernmost limits of the Altiplano endorheic watershed, which contained paleolake Tauca. Blard et al. (2014) generated a ${ }^{3} \mathrm{He}$ exposure age chronology using moraine boulders and striated bedrock from a formerly glaciated valley on the southern flank of Uturuncu volcano $\left(22.27^{\circ} \mathrm{S}, 67.19^{\circ} \mathrm{W}\right)$. Exposure ages were calculated using the production rate of cosmogenic ${ }^{3} \mathrm{He}$ calibrated at Tunupa volcano on the Pocolli fan (Blard et al., 2013b) on the Altiplano. The authors also reconstructed paleo-equilibrium line altitudes (ELA's) in order to evaluate relative ELA changes throughout the late Pleistocene.

Five (M1 to M5) successive moraine sets were identified. The widest and most distal M1 moraine complex (4810 m) exhibits several individual ridges. Five ${ }^{3} \mathrm{He}$ exposure ages were developed from the outermost dated M1 ridge; these yield 3 overlapping ages of $39.5 \pm 0.7,40.2 \pm 0.9$, and $46 \pm 2 \mathrm{ka}$, and two outliers of $65 \pm 2$ and $116 \pm 4 \mathrm{ka}$. By our interpretive methods, this suggests an age for M1 of $\sim 40 \mathrm{ka}$. The next, inner M1 ridge yielded 3 ages of $18.8 \pm 0.7,37.3 \pm 1.3$, and $62 \pm 2$. Either of these two younger ages are consistent stratigraphically with the outer M1 results.

The M2 moraine (4830 m) was deposited $\sim 250 \mathrm{~m}$ upvalley of the inner portion of M1 and displayed prominent (10 m wide, $2-4 \mathrm{~m}$ tall) frontal and lateral ridges and yielded four samples with ages of $15.9 \pm 0.6,21.4 \pm 0.9,32.7 \pm 1.6,33.5 \pm 0.9 \mathrm{ka}$. The two overlapping ages suggest that M2 dates to $\sim 33 \mathrm{ka}$, further implying $\sim 37 \mathrm{ka}$ for the inner M1 moraine. Field relationships support that $\mathrm{M} 2$ is indeed younger and even overrode M1. Recessional M3 and M4 moraines, another $250 \mathrm{~m}$ inboard, are less prominent than M2 and were not dated. Bedrock from roche moutonnée just inside the M4 moraine yielded two identical exposure ages of $17.5 \pm 0.6$ and $17.8 \pm 0.7$, implying retreat from the M4 position by $\sim 17-18 \mathrm{ka}$.

Farther upvalley, 3 samples from the M5 moraine gave exposure ages of $13.7 \pm$ $0.4,15.9 \pm 0.5$, and $62 \pm 2 \mathrm{ka}$, implying a 13-16 ka age for M5. Bedrock on valley side inside the M5 moraines and just below the M5 trimline yielded an age of $19.0 \pm 0.5 \mathrm{ka}$, and bedrock $400 \mathrm{~m}$ upvalley from the M5 moraine and near the valley thalweg yielded 3 ages of $14.2 \pm 0.5,15.5 \pm 0.6$, and $15.6 \pm 0.4 \mathrm{ka}$. These support a $\sim 16 \mathrm{ka}$ age for M5 and deglaciation by $14-15 \mathrm{ka}$.

Our conclusions are similar to those of the original authors. We interpret emplacement of the M1 and M2 moraine sets to have occurred between 46 and $33 \mathrm{ka}$, with the glacial front at $4800 \mathrm{~m}$ and an ELA as reconstructed by Blard et al. (2014) of $5250 \mathrm{~m}$. M3- and M4-proximal bedrock ages establish that the glacial front receded $\sim 1 \mathrm{~km}$ at $17 \mathrm{ka}$ and reached $4900 \mathrm{~m}$ to begin depositing M5. The emplacement of M5 is interpreted to be $\sim 16$ $\mathrm{ka}$, with a corresponding ELA of $5350 \mathrm{~m}$. The upper roche moutonnée samples indicate the onset of rapid valley deglaciation after a late glacial or Tauca stillstand. After $14 \mathrm{ka}$, ice had retreated to above $5100 \mathrm{~m}$. 


\subsection{Cerro La Torta (Ward et al., 2015)}

Ward et al. (2015) presented two ${ }^{10} \mathrm{Be}$ ages from a glacial valley near the dacite dome known as Cerro La Torta $\left(22.43^{\circ} \mathrm{S}, 67.99^{\circ} \mathrm{W}\right)$. Here, a narrow valley glacier flowed $\sim 4.5$ $\mathrm{km}$ from high terrain between two volcanic peaks and cross-cut broader moraine ridges and drift from the much wider valley to the east. The cross-cut drift is very thin $(<1 \mathrm{~m})$, with more than 20 individual ridges in the distal $2.5 \mathrm{~km}$, and patterned with polygonal hummocks of 50-150 m diameter in a manner similar to that of sublimation till (e.g., Marchant et al., 2002). One degraded moraine boulder from the narrow, cross-cutting moraine yielded an age of $24.7 \pm 1.8 \mathrm{ka}$, whereas a glaciated bedrock surface $\sim 500 \mathrm{~m}$ proximal to the moraine had an exposure age of $31 \pm 2.4 \mathrm{ka}$. Given the degraded state of the moraine boulder, the bedrock age was interpreted to better reflect the timing of deglaciation, although it is certainly possible that this surface contains some cosmogenic inheritance. Taking the moraine age as minimum-limiting and the bedrock age as maximum-limiting indicates that this position was last occupied between 25 and $30 \mathrm{ka}$. A less prominent moraine position is apparent at a distance of $\sim 800 \mathrm{~m}$ upvalley from the outer moraine and may represent the global LGM position, or a late glacial stage. No further moraines are apparent upvalley.

\subsection{Chajnantor Plateau (Ward et al., 2015; Cesta and Ward, 2016)}

Ward et al. (2015) presented a new ${ }^{36} \mathrm{Cl}$ and ${ }^{10} \mathrm{Be}$ chronology for the Chajantor Plateau $\left(23^{\circ} \mathrm{S}\right)$, where a $\sim 250 \mathrm{~km}^{2}$ ice cap covered a broad $5000 \mathrm{~m}$ elevation ignimbrite shield. Here, we rescaled the ${ }^{36} \mathrm{Cl}$ ages presented in that paper based on the LSD scaling scheme using the CRONUSCalc online calculator (Marrero et al., 2016a). Some of these ages changed significantly, while others changed only by a few $\%$ with rescaling. We have additionally included four new ages not presented in that paper (processed following similar methods to those outlined in Section 4, below). The overall conclusions from Ward et al. (2015) were not changed, but the record as presented here is more consistent with the other records in this review. The current suite of ages is shown in Figure 3.

Moraines on the Chajnantor Plateau group stratigraphically into three stages. Ward et al. (2015) classified these as Stages I-III, with Stage I the innermost, youngest stage; for consistency with other records in this review, we here relabel these as M1M3 moraines, with M1 being the outermost, oldest moraines. In most locations around the plateau, the M3 moraine is closely nested within the M2 moraine, to the point of being difficult to discriminate between the two, especially on the northern and eastern margins of the former ice cap. Separation of up to $\sim 1 \mathrm{~km}$ occurs along the western margin of the former ice cap. As mapped by Ward et al. (2015) the local M3 moraines vary from well-defined ridges up to $10 \mathrm{~m}$ height on the eastern margin to low, hummocky ridges perched on bedrock divides on the western margin. M2 moraines are the most prominent overall, generally comprising 3-10 m high ridges with many meter-scale boulders. M1 moraines are low and degraded, with few large boulders. In many cases M1 deposits are only recognizable as moraines due to their arcuate traces in map view, as visible in satellite imagery. 


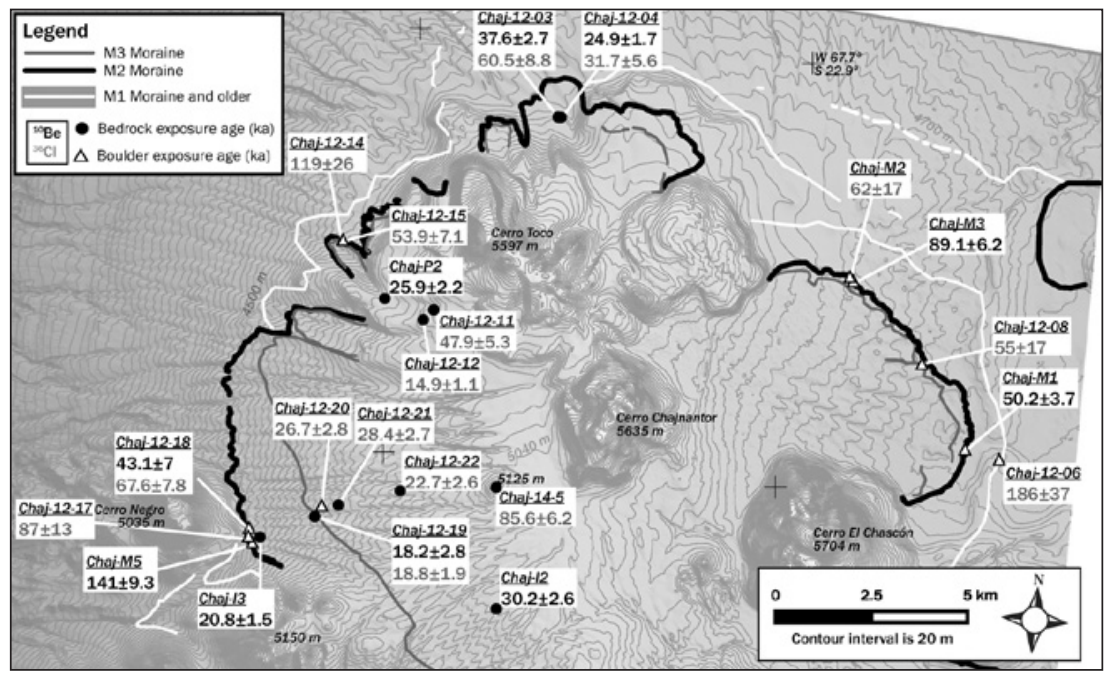

Figure 3. Map of the Chajnantor plateau based on Ward et al. (2015) with updated ${ }^{36} \mathrm{Cl}$ ages (grey numbers). Moraines on the eastern margin appear to have been deposited ca. 50-60 ka, but the scatter and discordant ${ }^{10} \mathrm{Be}$ and ${ }^{36} \mathrm{Cl}$ paired ages imply significant cosmogenic inheritance at this site. Bedrock and boulder ages from the western interior of the plateau suggest deglaciation ca. 20-25 ka.

A single boulder sampled on a degraded M1 moraine on the eastern side of the Chajnantor Plateau yielded an age of $186 \pm 37 \mathrm{ka}$. Out of nine M2 moraine samples, five yield overlapping ages that range from $43.1 \pm 7$ to $62 \pm 17 \mathrm{ka}$, with outliers of 87 , 89,119 , and $141 \mathrm{ka}$. Two exposure ages on glaciated bedrock between M2 and M3 yield ages of $20.8 \pm 1.5$ and $18.2 \pm 2.8 \mathrm{ka}$. A M3 erratic boulder gives an age of $26.7 \pm 2.8 \mathrm{ka}$.

There are nine glaciated bedrock ages within the M3 moraines. Five of these cluster in the period 22-30 ka. There is one young outlier of $14.9 \pm 1.1 \mathrm{ka}$ and older outliers of $37.6 \pm 2.7$ and $47.9 \pm 1.1 \mathrm{ka}$. The last bedrock sample (Chaj-14-5) was taken from glaciated bedrock at the peak of Cerro Chico, a small peak in the center of the plateau. This sample gives a ${ }^{36} \mathrm{Cl}$ exposure age of $85 \pm 6.2 \mathrm{ka}$, indicating that that Cerro Chico was likely either a nunatak or only shallowly covered with ice during the most recent glaciation of the plateau.

In general, young outliers in bedrock exposure ages may have experienced unusual transient shielding after glacial retreat, whereas older outliers contain cosmogenic inheritance because they experienced incomplete resetting by glacial erosion. There is substantial evidence that inheritance is a major problem in this dataset, both in moraine and bedrock samples. First, the youngest of the 21-30 ka cluster of bedrock ages are found in samples from lower elevations and more distal positions, where ice may have been warmer-based and more erosive. Second, most moraine boulder ages are significantly older than most of the nearby, ice-proximal bedrock samples, and exhibit considerable scatter on the same landforms. Third, in three of four samples dated with both ${ }^{10} \mathrm{Be}$ and ${ }^{36} \mathrm{Cl}$, the ${ }^{36} \mathrm{Cl}$ age is $30-50 \%$ older than the ${ }^{10} \mathrm{Be}$ age, indicating 
incomplete resetting of these samples $\left({ }^{36} \mathrm{Cl}\right.$ has a deeper production profile than ${ }^{10} \mathrm{Be}$, and is therefore not as easily reset by erosion; e.g. Wirsig et al., 2016). Only in the youngest sample (Chaj-12-19) are the ${ }^{10} \mathrm{Be}$ and ${ }^{36} \mathrm{Cl}$ ages identical, although in the second-youngest (Chaj-12-04) ages based on the two nuclides overlap within error. Although there is significantly more uncertainty in the ${ }^{36} \mathrm{Cl}$ production rate scaling, particularly beyond $20 \mathrm{ka}$ (Marrero et al., 2016b), the divergence of ages with increasing age is indicative of incomplete erosional resetting, and consistent with the other evidence for inheritance in the dataset.

In light of the evidence for at least locally incomplete resetting of cosmogenic ages, our interpreted timing of the most prominent M2 stage is biased toward the young end of the range 40-60 ka, based on the overlapping moraine boulder ages. Following the same argument, the bedrock ages indicate deglaciation of the plateau interior by $\sim 18-25 \mathrm{ka}$, during the global LGM.

Along the western flank of the Chajnantor Plateau, a broad bajada extends from the base of the plateau to the margin of the Salar de Atacama. Coalescing gravel fans and debris flows of this alluvial apron emanate from large bedrock canyons (quebradas) and smaller, fracture-controlled bedrock channels. The gravel fans of the Chajnantor bajada form a gently undulating surface, and three regional alluvial fan surfaces (Qf1 [oldest], Qf2, and Qf3 [youngest]) are observed. The Qf1 and Qf2 surfaces represent hyperconcentrated flow deposits, predominantly composed of andesitic to dacitic gravels, while the Qf3 surface represents boulder-rich debris flow deposits composed of ignimbrite and andesite clasts.

Cosmogenic ${ }^{36} \mathrm{Cl}$ exposure ages on these alluvial fan surfaces date the timing of abandonment to $175 \pm 22.6 \mathrm{ka}, 134.5 \pm 9.18 \mathrm{ka}$, and $20.07 \pm 6.26 \mathrm{ka}$, respectively (Cesta and Ward,2016). The exposure ages indicate two main phases of alluvial fan development. The first phase of alluvial fan aggradation occurred prior to or during MIS 6 and likely resulted in the main period of bajada development, evident from the extensive Qf1 and Qf2 fans. This phase of alluvial development was followed period of quiescence in fan formation, which ended with the initiation of the second phase of fan aggradation during MIS 2. The second major phase of alluvial fan development resulted in the formation and abandonment of the Qf3 surface, characterized by localized, proximal aggradation of debris flow deposits within fluvial channels.

\subsection{Encierro Valley (Zech et al., 2006)}

In the Encierro Valley $\left(29.10^{\circ} \mathrm{S}, 69.90^{\circ} \mathrm{W}\right)$, drift and moraines indicate that a $16 \mathrm{~km}$ long glacier occupied the north-flowing valley axis. A $1.8 \mathrm{~km}$ long rock glacier exists in the headwaters today. Zech et al. (2006) used ${ }^{10} \mathrm{Be}$ to date boulders from several moraine positions. (Ages from this site are presented as rescaled by Ward et al. [2015] using the time-varying Lal-Stone scheme). One outer terminal boulder gives $35 \pm 2.6 \mathrm{ka}$. A terminal moraine located $\sim 0.3 \mathrm{~km}$ proximal to this outer moraine and associated lateral moraines yielded 6 samples of which four lie between 18-21 ka, with outliers of $13.9 \pm 1.0$ and $16.7 \pm 1.4 \mathrm{ka}$. More proximal moraine positions were dated to $15-17 \mathrm{ka}$. Small lateral 
moraines are apparent in satellite imagery between these late glacial moraines and the extant large rock glacier, and are locally overridden by talus and small rock glaciers.

\subsection{Cerro Tapado (Sagredo et al., 2016)}

Cerro Tapado $\left(30.14^{\circ} \mathrm{S} ; 69.93^{\circ} \mathrm{W} ; 5536 \mathrm{~m}\right.$ asl $)$, receives most of its precipitation from winter cut-offs of cold air-masses from the Pacific (Vuille and Ammann, 1997; Ginot et al., 2002; Marengo et al., 2004). The southeast slope of Cerro Tapado hosts a $\sim 1.5 \mathrm{~km}$-long glacier (Schotterer et al., 2003), which has an estimated ELA of $5300 \mathrm{~m}$ (Kull et al., 2002) and terminates near $4700 \mathrm{~m}$. With a surface area of $\sim 1.2 \mathrm{~km}^{2}$, this is the northernmost significant glacier in the western cordillera south of the Arid Diagonal, and its mass balance is strongly influenced by sublimation (Ginot et al., 2006). The presence of the glacier is somewhat unusual, in that peaks of similar elevation at this latitude are presently deglaciated (Stichler et al., 2001).

The distal ice of Tapado glacier is partly debris-covered, and its forefield is occupied by several rock glaciers of different ages, along with debris-covered ice and ice-cored moraines. Sagredo et al. (2016) interpret several moraine stages. Innermost is a moraine complex among debris-covered ice about $200 \mathrm{~m}$ below and $500 \mathrm{~m}$ downvalley from the current terminus. Distal to the inner moraines and the rock glacier fields are remnants of several older lateral moraines. Sagredo et al. (2016) used ${ }^{36} \mathrm{Cl}$ to date samples from the more distal, lateral moraines, which yielded ages of $3040 \pm 330$ and $5100 \pm 290 \mathrm{yr}$ BP. Samples from the crest of the inner moraines yield ages of $490 \pm 130 \mathrm{yr} \mathrm{BP}, 540 \pm$ $70 \mathrm{yr} \mathrm{BP}, 780 \pm 100 \mathrm{yr} \mathrm{BP}, 950 \pm 90 \mathrm{yr} \mathrm{BP}$ and $1830 \pm 270 \mathrm{yr}$ BP. The inner moraine is interpreted as being deposited between 500-1000 yr BP. The more distal moraines, on the other hand, were probably deposited during the mid-Holocene (Sagredo et al., 2016).

\subsection{Cordón de Doña Rosa (Zech et al., 2007)}

Zech et al. (2007) dated many locations along a deglaciated valley in the Cordón de Doña Rosa $\left(30.7^{\circ} \mathrm{S}\right)$. (Ages from this site are presented as rescaled by Ward et al. (2015) using the time-varying Lal-Stone scheme). Of seven samples on the outer moraines and drift ( $\sim 10 \mathrm{~km}$ from the headwall), five yield rescaled ${ }^{10} \mathrm{Be}$ ages of $36-49 \mathrm{ka}$, plus one $22.1 \pm 1.6 \mathrm{ka}$ age and one $148 \pm 10 \mathrm{ka}$ age. Approximately $4 \mathrm{~km}$ upvalley, a set of moraines is apparent in each of two primary tributaries. The eastern tributary moraine extends below the junction into the main valley, and gives three consistent ages of $17.3 \pm 1.4,17.8 \pm 1.3$, and $18.3 \pm 1.4 \mathrm{ka}$. In the western tributary, six samples from a sequence of three moraines yield ages of: $17.3 \pm 1.3,21.5 \pm 1.5$, and $19.3 \pm 1.3 \mathrm{ka}$ (outermost of this group); $25.7 \pm 1.9 \mathrm{ka}$ (middle); and $17.3 \pm 1.2$ and $19.0 \pm 1.4 \mathrm{ka}$ (innermost). In the context of the scatter, all three moraines were likely emplaced between 21.5 and $17 \mathrm{ka}$, with the innermost position likely corresponding to the 17-18 ka moraine in the eastern tributary. There is excellent bedrock exposure higher in the headwaters of the western tributary, but this was not dated, and no younger moraines are apparent. It is therefore reasonable that this valley was fully deglaciated shortly after 17 ka. Only a very small rock glacier is apparent there today. 
Six boulders were dated from three sites 9, 16, and $21 \mathrm{~km}$ downvalley of the outer moraines, and four of these yielded similar ages of 30-40 ka. These sites were interpreted by Zech et al. (2007) as representing degraded moraine fragments; the authors disregarded these ages as they did not make stratigraphic sense. Using newer, higher-resolution imagery from Google Earth, we interpret that these samples were not from moraines. Instead, they appear to be from dissected fluvial fill terraces overlain by colluvial fans. The consistent $\sim 35 \mathrm{ka}$ age of these samples could represent fluvial incision and terrace abandonment coincidental with glacial retreat from the $\sim 35-40$ ka moraines.

\section{New ${ }^{36} \mathrm{Cl}$ results from Cordillera del Tatio and Sairecabur}

\subsection{El Tatio moraines}

In the Cordillera del Tatio, moraines and other drift are clear indicators that wellorganized valley glaciers existed in the past. The most well-known of these deposits $\left(22.30^{\circ} \mathrm{S}, 67.98^{\circ} \mathrm{W}, 4100-4500 \mathrm{~m}\right)$ lies a few $\mathrm{km}$ north of the El Tatio geyser field and is perhaps the best expression of valley glaciation in the region, with high, sharp lateral moraines grading into a clear terminal complex with no evidence for stagnant ice (Fig. 4). Much of the drift surrounding this valley, on the other hand, is thin and exhibits patterning (as described above in Section 3.4) and poor development of lateral moraines, all of which may indicate thin, cold-based ice. Glacial-climate modeling by Kull and Grosjean (2000) based on the prominent moraines indicated that an extra $1 \mathrm{~m}$

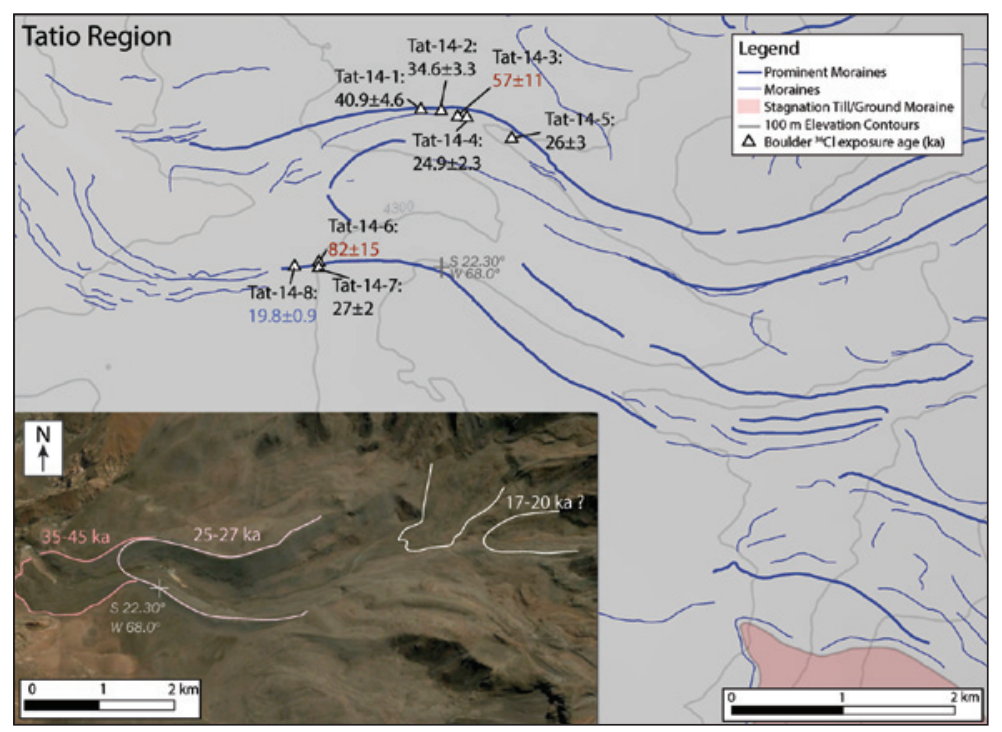

Figure 4. Glaciers and sample locations at El Tatio. Ages interpreted as old outliers due to inheritance shown in red, and as young outliers due to moraine degradation shown in blue. Inset: same region shown on map, with glacial stage interpretation based on cosmogenic ages and regional context. Image from Google Earth, 2016 CNES/Astrium. 
of precipitation could be necessary to generate this glacier in conjunction with a $3.5^{\circ} \mathrm{C}$ temperature depression as was characteristic of the Late Glacial. The model indicated, based on modern precipitation patterns, that most of this moisture must have come from the east during the austral summer.

The prominent moraines of the glacier modeled by Kull and Grosjean (2000) have not, however, been previously dated. Here, we present 8 new cosmogenic ${ }^{36} \mathrm{Cl}$ exposure ages. From the most distal, lower moraines several overlapping deposits may be present, with a broad, slightly degraded set of terminal and laterally distal moraines inset by a less-prominent drift of lateral and ground moraines. On the sharp lateral crests of the inner position, four exposure ages of $19.8 \pm 0.9,24.9 \pm 2.3,26 \pm 3$, and $27 \pm 2$ ka indicate deposition prior to or during the global LGM. Two samples in slightly more laterally distal positions give exposure ages of $34.6 \pm 3.3$ and $40.9 \pm 4.6 \mathrm{ka}$. These are on the outer flanking moraines that can be traced around the farthest terminus of the glacier (Fig. 4), compatible with regional ages indicating early glaciation at 35-40 ka. Two outliers yield ages of $57 \pm 11$ and $82 \pm 15 \mathrm{ka}$, attributable to cosmogenic inheritance. At least two more proximal sets of less-prominent moraines are present several $\mathrm{km}$ upvalley, and could correspond to global LGM and late glacial pauses in the retreat.

\subsection{Sairecabur moraines}

An $\sim 8 \mathrm{~km}$ glacier flowed west from the valley now occupied by the post-glacial northern edifice of Sairecabur and deposited moraines near $4600 \mathrm{~m}\left(22.71^{\circ} \mathrm{S}, 67.94^{\circ} \mathrm{W}\right.$; Fig. 5). The distal moraine complex occupies the lower $\sim 1.5 \mathrm{~km}$ length of the former glacial footprint, and can be described as an outer, prominent, lobate moraine, and an inner hummocky moraine, with patterned, hummocky ridges in between. The morphology suggests that these were likely ice-cored moraines. It is possible, but not clear from the morphology, that the overall complex was deposited by stagnant, debris-laden ice or a detached rock glacier.

Cosmogenic ${ }^{36} \mathrm{Cl}$ ages yield widely scattered ages. Seven samples from the outer moraine ridge give exposure ages of $13.1 \pm 1.9,14.3 \pm 0.9,18 \pm 2,27.6 \pm 3.3,42.5 \pm$ $4.8,92 \pm 13$, and $123 \pm 12 \mathrm{ka}$. Two samples from the inner hummocky moraines yield overlapping ages of $41.3 \pm 5.1$ and $48.6 \pm 4.8 \mathrm{ka}$.

This map pattern of ages defies straightforward interpretation. The only two overlapping ages on the outer moraine are 13-14 ka. The other five samples from this moraine are distributed approximately evenly over the last $120 \mathrm{ka}$. The two samples from the inner, hummocky moraines imply an age of 41-49 ka, in stratigraphic conflict with a younger outer ridge. Given the regional context, we hypothesize that the valley was last glaciated synchronously with the other local glaciated valleys ca. 30-40 ka, and this advance overrode and incorporated some older materials. Nonetheless, there are many plausible scenarios involving cosmogenic inheritance and moraine degradation that could result in the scattered exposure ages on these deposits, so the most confident interpretation must be that the valley was glaciated at some point between $123 \mathrm{ka}$ and $13 \mathrm{ka}$, and that the distal portion of the glacier was debris-covered and possibly stagnant prior to deglaciation. We do not use this site in considering the regional pattern of deglaciation. 


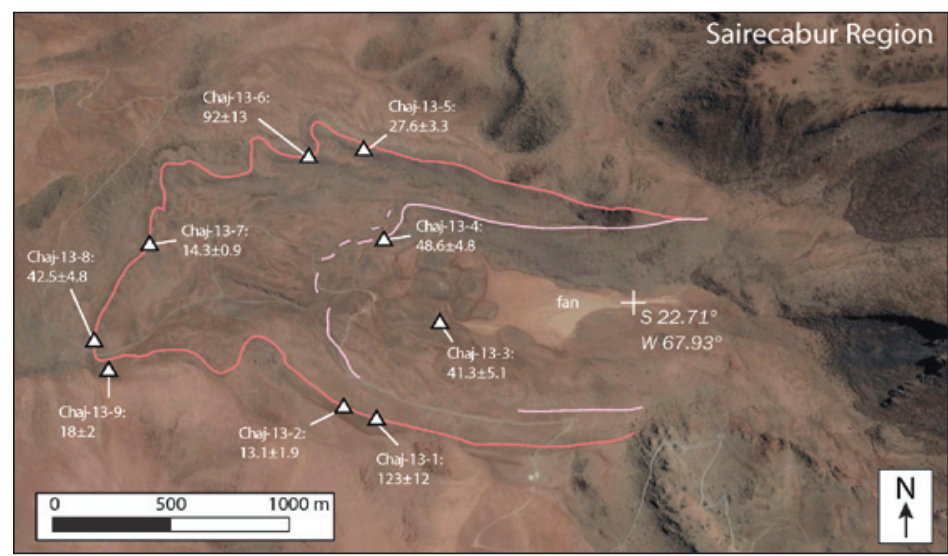

Figure 5. Moraines and sample locations near Sairecabur. Note the deformed hummocky ridges between the key moraine stages, and the "splintered" lobes of the outer margin, possibly indicating stagnant or cold-based ice. Image from Google Earth, 2016 CNES/Astrium.

\section{Discussion}

Deglaciation trends in the western cordillera of the Andes vary by location, and the locations fall into three main groups with roughly similar behavior within each group (Fig. 6). These groups are the outer tropical and paleolake Tauca-proximal glaciers of Nevado Sajama and Cerro Tunupa; the Arid Andes glacier deposits north of the Arid Diagonal, comprising Cerro Uturuncu, El Tatio, Cerro Tapado, Sairecabur, and Chajnantor; and the subtropical glaciers south of the Arid Diagonal, comprising Valle de Encierro, Cordón de Doña Rosa, and Cerro Tapado.

Where dated, the outer, degraded moraines throughout the region date to within Marine Isotope Stage 6 (130-191 ka). Greater precision is not possible with the available data, but this timing corresponds to deposition of the broad bajada along the Salar de Atacama (Cesta and Ward, 2016). The next stage of more prominent moraines returns ages generally between 35-45 ka on both sides of the Arid Diagonal. Locally, the wellpreserved moraines of the next innermost stage date to $25-30 \mathrm{ka}, \sim 19-22 \mathrm{ka}$, or 15-17 ka, with several of these stages apparent in some locations but not always independently dated. North of the Arid Diagonal, it is common to find moraines that date to $<15 \mathrm{ka}$. South of the Arid Diagonal, this is not typical, implying rapid deglaciation after $17 \mathrm{ka}$, except at Cerro Tapado, where a modern glacier remains.

The presence of a $40 \mathrm{ka}$ glacial stage in the Andes has been suggested before. Zech et al. (2008) argues for a $\sim 40 \mathrm{ka}$ advance based on a review of records in Patagonia and south-central Chile. Recent cosmogenic glacial records both from the tropics (e.g., Bromley et al., 2016) and subtropical Argentina (e.g., Moreiras et al., 2016) indicate moraine formation at ca. $40 \mathrm{ka}$ and $25 \mathrm{ka}$. (More complete reviews of deglaciation in adjacent regions are included in this volume.) This would place the beginning of the regional LGM around the time of the $46 \mathrm{ka}$ Inca Huasi highstand of the Altiplanic lakes, and synchronous with a deep lake at Pozuelos Basin in Argentina (McGlue et al., 2013). 


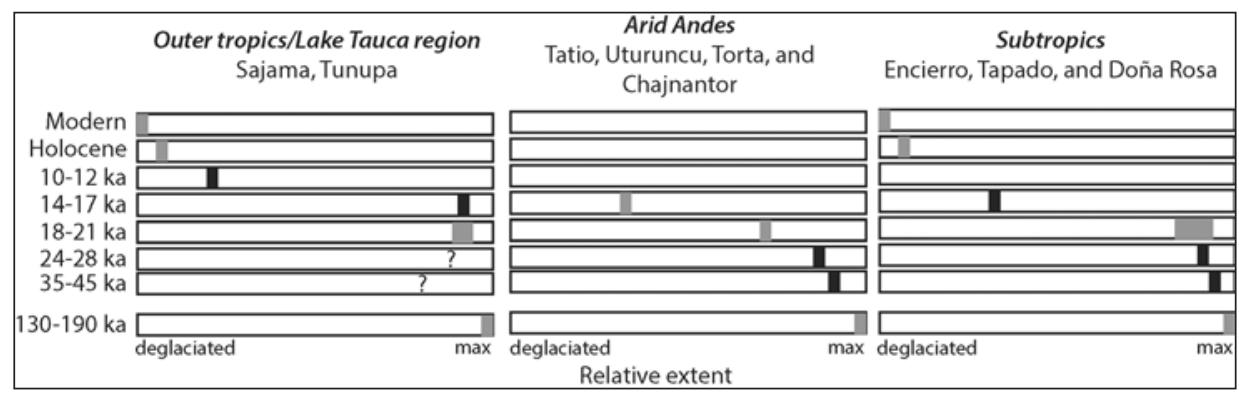

Figure 6. Schematic deglaciation history of the three main portions of the study region. Bars correspond to regionally identified moraine stages. Black markings indicate relative position of moraines identified in most or all records in that region, whereas gray markings indicate positions of stages identified in few or some locations in the region. In the northeastern outer tropicall Lake Tauca region, the Tauca phase (14-17 ka) glacial advance overrode most older moraines. In contrast, in the arid Andes and subtropical regions, the most prominent nested moraines appear to correspond to ca.35-45 ka and 24-28 ka, with later phases identified at more retracted positions. Rapid deglaciation occurred ca. $17 \mathrm{ka}$ in the subtropics, in contrast with slightly later deglaciation in the Tauca region. Scattered older moraines dating to 130-190 ka are found in all three regions.

Modern and Holocene stages are seen only at Sajama, in the north, and Tapado, in the south.

In the outer tropical and Tauca-proximal glaciation records reviewed here, moraines dating to the global LGM and earlier were overridden during the Tauca highstand wet phase ( 15-17 ka). Blard et al. (2014) attribute a downward shift in glacial equilibrium lines at this time near paleolake Tauca (Fig. 1) to a local positive feedback of increased precipitation over the lake, which was synchronous with an $80 \%$ increase in regional precipitation (Blodgett et al., 1997; Blard et al., 2009). Rapid deglaciation at Cerro Tunupa and disappearance of lake Tauca are synchronous with a temperature increase apparent in the NorthGRIP ice core from Greenland and in East Pacific sea surface temperature proxies. Blard et al. $(2009,2014)$ invoke a mechanism by which the warming of the North Atlantic and tropics after the Heinrich 1 stadial event shifted the South American monsoon northward. This resulted in drying and warming on the Altiplano after $14.5 \mathrm{ka}$.

Later late glacial deposits in tropical and subtropical South America have been interpreted as corresponding either to the Northern Hemisphere Younger Dryas stadial event (YD; 12.9-11.7 ka) or the Southern Hemisphere Antarctic Cold Reversal (ACR; 14.5-12.8 ka). A reasonable hypothesis would be that the Arid Diagonal would demarcate the boundary of influence between these hemispheric effects, but reviews of glacial chronologies have remained inconclusive on this matter (Ward et al., 2015), with some workers (e.g., Jomelli et al., 2014) suggesting that the timing of glacial advances in tropical South America indicates an influence of the ACR there. Among the sites considered here, only the two northernmost appear to have late glacial positions that could correspond to either the YD or the ACR. At Nevado Sajama, bedrock ages in the lower main valleys imply that they were occupied until ca. $11 \mathrm{ka}$, supporting a YD influence. On the other hand, at Cerro Tunupa, the innermost position indicates a short stillstand that dates to 12-14 ka, conceivably during the ACR. At Cerro Uturuncu and 
all records farther south, the youngest pre-Holocene positions are 14-15 ka, implying that deglaciation was proceeding during both the YD and the ACR. We reiterate that the nature of the dating methods and the scatter in the resulting ages make these records insufficiently precise to distinguish between the YD and the ACR.

During the late-glacial Tauca phase, a sharp spatial gradient in the glacial climate occurred between Cerro Tunupa, which is located at the geographic center of Lake Tauca, and Cerro Uturuncu, just south of the southern end of Lake Tauca and the Salar de Uyuni and the other arid Andean glaciers north of the Arid Diagonal. Blard et al. (2014) point out that the inferred ELA based on the Tauca-phase moraine at Uturuncu was $5350 \mathrm{~m}$, and at Tunupa the corresponding ELA was $4450 \mathrm{~m}$. The spatial gradient in temperature between these locations (e.g.,Ammann et al., 2001) is not sufficient to explain the $900 \mathrm{~m}$ difference, implicating strong spatial gradients in moisture availability moving south from the southern margin of Lake Tauca. This is supported by the lack of a clear Tauca-phase transgression at Pozuelos Basin in the Puna region, at a similar latitude to Co. Uturuncu and El Tatio (McGlue et al., 2013). Within the arid Andes group of glacial records, the Tauca-phase moraine is either absent or found high in the glacial valleys, and does not appear to be one of the more extensive glacial positions.

The glacier-climate modeling of Kull and Grosjean (2000) matched the El Tatio glacier to its most extensive moraines with a regional temperature depression of $\sim 3.5^{\circ} \mathrm{C}$, and with radiation climate consistent with that of ca. $17 \mathrm{ka}$. Given these conditions, an extra meter of precipitation would be required to generate a glacier of the correct size. It is not clear what mechanisms might have been able to increase regional precipitation to this extent, even during peak Tauca phase. Proxies at this time indicate perhaps a doubling of modern precipitation from $\sim 300$ to $\sim 600 \mathrm{~mm} / \mathrm{yr}$ (e.g., Grosjean et al., 2001; Maldonado et al., 2005; Gayo et al., 2012). The indication by the new cosmogenic ages that the extensive moraines in these areas do not date to Tauca phase may place peak glaciation in the arid Andes during a colder period such as mid-global LGM, when temperatures were likely $5-7^{\circ}$ colder, and therefore less precipitation would be needed to glaciate the region than previously modeled. In support of this idea, south of the Arid Diagonal, Kull et al. (2002) used similar methods at Encierro Valley to estimate that a $+580 \pm 150 \mathrm{~mm}$ increase in precipitation, coupled with a $5.7^{\circ} \mathrm{C}$ temperature decrease typical of the global LGM in this area, would match the observed deposits.

\section{Conclusions}

Recent cosmogenic dating at formerly glaciated sites spanning the South American Arid Diagonal in the western cordillera of the Andes suggests that glaciation associated with the global LGM began ca. 35-45 ka throughout the region. Dry, cold conditions led to slow retreat during the global LGM (through $20-25 \mathrm{ka}$ ) and possibly the formation of stagnant ice where debris cover and glacier geometry were appropriate. These earlier moraines were overridden in most parts of the tropics and Lake Tauca-proximate regions between $15-17 \mathrm{ka}$ as a result of local moisture availability on the Altiplano associated with the Tauca highstand. Just south and west of the southern Altiplano, retreat continued through the Tauca phase with no major readvance apparent at that time, only minor 
moraines at retracted positions. In the subtropical Andes south of the Arid Diagonal, the deglaciation history was similar. In both of these more southerly regions, there are no apparent deposits between the 14-17 ka positions and the few modern glaciers and rock glaciers present high in the catchments.

The cosmogenic ages reviewed here suggest that the glaciers north and south of the Arid Diagonal behaved more or less synchronously throughout the deglaciation. The more important transition in deglaciation pattern appears to lie near the southern end of the Salar de Uyuni, where the regional influence of late glacial Lake Tauca tapered off. This conclusion leads to the intriguing hypothesis that the influence of tropical moisture on the Altiplano during the late glacial reached farther south than it otherwise would have due to the great extent of Lake Tauca.

\section{Acknowledgements}

Support for this work was provided by US National Science Foundation award EAR-1226611 (GLD) and by Geological Society of America Student Research Grants to Cesta and Thornton. We thank Marc Caffee, J. Radler, and Greg Chmiel at PRIME lab for assistance and advice with the ${ }^{36} \mathrm{Cl}$ dating. Colby Smith graciously provided raw sample data to aid in rescaling ages. We thank two anonymous reviewers for their careful reading of our original submission and comments that resulted in a much clearer manuscript.

\section{References}

Ammann, C., Jenny, B., Kammer, K., Messerli, B. 2001. Late Quaternary glacier response to humidity changes in the arid Andes of Chile (18-29' $\mathrm{S})$. Palaeogeography, Palaeoclimatology, Palaeoecology 172 (3), 313-326. http://doi.org/10.1016/S0031-0182(01)00306-6.

Baker, P.A., Fritz, S.C. 2015. Nature and causes of Quaternary climate variation of tropical South America. Quaternary Science Reviews 124, 31-47. http://doi.org/10.1016/j. quascirev.2015.06.011.

Balco, G., Stone, J.O., Lifton, N.A., Dunai, T.J. 2008. A complete and easily accessible means of calculating surface exposure ages or erosion rates from ${ }^{10} \mathrm{Be}$ and ${ }^{26} \mathrm{Al}$ measurements. Quaternary Geochronology 3 (3), 174-195. http://doi.org/10.1016/j.quageo.2007.12.001.

Blard, P.H., Lavé, J., Farley, K.A., Fornari, M., Jiménez, N., Ramirez, V. 2009. Late local glacial maximum in the Central Altiplano triggered by cold and locally-wet conditions during the paleolake Tauca episode (17-15ka, Heinrich 1). Quaternary Science Reviews 28 (27), 34143427.

Blard, P.H., Braucher, R., Lavé, J., Bourlès, D. 2013a. Cosmogenic ${ }^{10}$ Be production rate calibrated against $3 \mathrm{He}$ in the high Tropical Andes (3800-4900 m, 20-22 $\left.{ }^{\circ} \mathrm{S}\right)$. Earth and Planetary Science Letters 382, 140-149. http://doi.org/10.1016/j.epsl.2013.09.010.

Blard, P.H., Lavé, J., Sylvestre, F., Placzek, C.J., Claude, C., Galy, V., Condom, T., Tibari, B. 2013b. Cosmogenic ${ }^{3} \mathrm{He}$ production rate in the high tropical Andes $\left(3800 \mathrm{~m}, 20^{\circ} \mathrm{S}\right)$ : implications for the local last glacial maximum. Earth and Planetary Science Letters 377, 260-275. http://doi. org/10.1016/j.epsl.2013.07.006.

Blard, P.H., Lave, J., Farley, K.A., Ramirez, V., Jimenez, N., Martin, L.C., Charreau, J., Tibari, B., Fornari, M. 2014. Progressive glacial retreat in the Southern Altiplano (Uturuncu volcano, $22^{\circ} \mathrm{S}$ ) between 65 and $14 \mathrm{ka}$ constrained by cosmogenic ${ }^{3} \mathrm{He}$ dating. Quaternary Research 82 (1), 209-221. http://doi.org/10.1016/j.yqres.2014.02.002. 
Blodgett, T.A., Isacks, B.L., Lenters, J.D. 1997. Constraints on the origin of paleolake expansions in the central Andes. Earth Interactions 1 (1), 1-28.

Bobst, A.L., Lowenstein, T.K., Jordan, T.E., Godfrey, L.V., Ku, T.L., Luo, S. 2001. A $106 \mathrm{ka}$ paleoclimate record from drill core of the Salar de Atacama, northern Chile. Palaeogeography, Palaeoclimatology, Palaeoecology 173 (1), 21-42. http://doi.org/10.1016/ S0031-0182(01)00308.

Bromley, G.R., Schaefer, J.M., Hall, B.L., Rademaker, K.M., Putnam, A.E., Todd, C.E., Hegland, M., Winckler, G., Jackson, M.S., Strand, P.D. 2016. A cosmogenic ${ }^{10}$ Be chronology for the local last glacial maximum and termination in the Cordillera Oriental, southern Peruvian Andes: Implications for the tropical role in global climate. Quaternary Science Reviews 148, 54-67. http://doi.org/10.1016/j.quascirev.2016.07.010.

Casassa, G., Haeberli, W., Jones, G., Kaser, G., Ribstein, P., Rivera, A., Schneider, C. 2007. Current status of Andean glaciers. Global and Planetary Change 59 (1), 1-9. http://doi.org/10.1016/j. gloplacha.2006.11.013.

Cesta, J.M., Ward, D.J. 2016. Timing and nature of alluvial fan development along the Chajnantor Plateau, northern Chile. Geomorphology 273, 412-427. http://doi.org/10.1016/j. geomorph.2016.09.003.

Cook, K.H., Vizy, E.K. 2006. South American climate during the Last Glacial Maximum: delayed onset of the South American monsoon. Journal of Geophysical Research: Atmospheres 111 (D2). http://doi.org/10.1029/2005JD005980.

De Martonne, E. 1934. The Andes of the North-West Argentine. The Geographical Journal 84 (1), 1-14.

Denton, G.H., Anderson, R.F., Toggweiler, J.R., Edwards, R.L., Schaefer, J.M., Putnam, A.E. 2010. The last glacial termination. Science 328 (5986), 1652-1656. doi:10.1126/science.1184119.

Gayo, E.M., Latorre, C., Jordan, T.E., Nester, P.L., Estay, S.A., Ojeda, K.F., Santoro, C.M. 2012. Late Quaternary hydrological and ecological changes in the hyperarid core of the northern Atacama Desert ( 21 $\left.{ }^{\circ} \mathrm{S}\right)$. Earth-Science Reviews 113 (3), 120-140. http://doi.org/10.1016/.j. earscirev.2012.04.003.

Garreaud, R. 2000. Intraseasonal variability of moisture and rainfall over the South American Altiplano. Monthly Weather Review 128 (9), 3337-3346.

Garreaud, R., Vuille, M., Clement, A.C. 2003. The climate of the Altiplano: observed current conditions and mechanisms of past changes. Palaeogeography, Palaeoclimatology, Palaeoecology 194 (1), 5-22. http://doi.org/10.1016/S0031-0182(03)00269-4.

Garreaud, R., Aceituno, P. 2001. Interannual rainfall variability over the South American Altiplano. Journal of Climate 14 (12), 2779-2789. http://doi.org/10.1175/1520-0442(2001)014<2779:IR VOTS>2.0.CO;2.

Ginot, P., Kull, C., Schotterer, U., Schwikowski, M., Gäggeler, H.W. 2006. Glacier mass balance reconstruction by sublimation induced enrichment of chemical species on Cerro Tapado (Chilean Andes). Climate of the Past 2 (1), 21-30. http://doi.org/10.5194/cp_2-21-2006.

Gosse, J.C., Phillips, F.M. 2001. Terrestrial in situ cosmogenic nuclides: theory and application. Quaternary Science Reviews 20 (14), 1475-1560. http://doi.org/10.1016/S02773791(00)00171-2.

Grenon, M. 2007. Nature Around the ALMA Site-Part 1. The Messenger 127. European Southern Observatory (http://www.eso.org).

Grosjean, M., van Leeuwen, J.F.N., Van der Knaap, W.O., Geyh, M.A., Ammann, B., Tanner, W., Messerli, B., Núñez, L.A., Valero-Garcés, B.L., Veit, H. 2001. A 22,000 ${ }^{14}$ C year BP sediment and pollen record of climate change from Laguna Miscanti $\left(23^{\circ} \mathrm{S}\right)$, northern Chile. Global and Planetary Change 28 (1), 35-51. http://doi.org/10.1016/S0921-8181(00)00063-1.

Hartley, A. 2003. Andean uplift and climate change. Journal of the Geological Society 160 (1), 7-10. http://doi.org/10.1144/0016-764902-083. 
Houston, J. 2006. The great Atacama flood of 2001 and its implications for Andean hydrology. Hydrological Processes 20 (3), 591-610. http://doi.org/10.1002/hyp.5926.

Jenny, B., Kammer, K., Ammann, C. 1996. Climate change in den trockenen Anden. Verlag des Geographischen Institutes der Universität Bern.

Jomelli, V., Favier, V., Vuille, M., Braucher, R., Martin, L., Blard, P.H., Colose, C., Brunstein, D., He, F., Khodri, M., Bourlès, D.L. 2014. A major advance of tropical Andean glaciers during the Antarctic cold reversal. Nature 513, 224-228. http://doi.org/10.1038/nature13546.

Kanner, L.C., Burns, S.J., Cheng, H., Edwards, R.L. 2012. High-latitude forcing of the South American summer monsoon during the last glacial. Science 335 (6068), 570-573. http://doi. org/10.1126/science.1213397.

Kelly, M.A., Lowell, T.V., Applegate, P.J., Phillips, F.M., Schaefer, J.M., Smith, C.A., Kim, H., Leonard, K.C., Hudson, A.M. 2015. A locally calibrated, late glacial ${ }^{10} \mathrm{Be}$ production rate from a low-latitude, high-altitude site in the Peruvian Andes. Quaternary Geochronology 26, 70-85. http://doi.org/10.1016/j.quageo.2013.10.007.

Kull, C. and Grosjean, M. 1998. Albedo changes, Milankovitch forcing, and late Quaternary climate changes in the central Andes. Climate Dynamics 14 (12), 871-881. http://doi. org/10.1007/s003820050261.

Kull, C., Grosjean, M., Veit, H. 2002. Modeling modern and Late Pleistocene glacio-climatological conditions in the north Chilean Andes (29-30). Climatic Change 52 (3), 359-381. http://doi. org/10.1023/A:1013746917257.

Kull, C., Grosjean, M. 2000. Late Pleistocene climate conditions in the north Chilean Andes drawn from a climate-glacier model. Journal of Glaciology 46 (155), 622-632. http://doi. org/10.3189/172756500781832611.

Lenters, J.D., Cook, K.H. 1997. On the origin of the Bolivian high and related circulation features of the South American climate. Journal of the Atmospheric Sciences 54 (5), 656-678.

Levy, J.S., Marchant, D.R. and Head, J.W. 2006. Distribution and origin of patterned ground on Mullins Valley debris-covered glacier, Antarctica: the roles of ice flow and sublimation. Antarctic Science 18 (3), 385-397. http://doi.org/10.1017/S0954102006000435.

Lifton, N., Sato, T., Dunai, T.J. 2014. Scaling in situ cosmogenic nuclide production rates using analytical approximations to atmospheric cosmic-ray fluxes. Earth and Planetary Science Letters 386, 149-160. http://doi.org/10.1016/j.epsl.2013.10.052.

Maldonado, A., Betancourt, J.L., Latorre, C., Villagran, C. 2005. Pollen analyses from a 50,000yr rodent midden series in the southern Atacama Desert (25 30' S). Journal of Quaternary Science 20 (5), 493-507. http://doi.org/10.1002/jqs.936.

Marchant, D.R., Lewis, A.R., Phillips, W.M., Moore, E.J., Souchez, R.A., Denton, G.H., Sugden, D.E., Potter, N., Landis, G.P. 2002. Formation of patterned ground and sublimation till over Miocene glacier ice in Beacon Valley, southern Victoria Land, Antarctica. Geological Society of America Bulletin 114 (6), 718-730.

Marengo, J.A., Soares, W.R., Saulo, C., Nicolini, M. 2004. Climatology of the low-level jet east of the Andes as derived from the NCEP-NCAR reanalyses: characteristics and temporal variability. Journal of Climate 17 (12), 2261-2280.

Marrero, S.M., Phillips, F.M., Borchers, B., Lifton, N., Aumer, R., Balco, G. 2016a. Cosmogenic nuclide systematics and the CRONUScalc program. Quaternary Geochronology 31, 160187. http://doi.org/10.1016/j.quageo.2015.09.005.

Marrero, S.M., Phillips, F.M., Caffee, M.W., Gosse, J.C. 2016b. CRONUS-Earth cosmogenic ${ }^{36} \mathrm{Cl}$ calibration. Quaternary Geochronology 31, 199-219. http://doi.org/10.1016/j. quageo.2015.10.002.

Mather, A.E., Hartley, A. 2005. Flow events on a hyper-arid alluvial fan: Quebrada Tambores, Salar de Atacama, northern Chile. Geological Society, London, Special Publications 251 (1), 9-24. http://doi.org/10.1144/GSL.SP.2005.251.01.02. 
McGlue, M.M., Cohen, A.S., Ellis, G.S., Kowler, A.L. 2013. Late Quaternary stratigraphy, sedimentology and geochemistry of an underfilled lake basin in the Puna plateau (northwest Argentina). Basin Research 25 (6), 638-658. http://doi.org/10.1111/bre.12025.

Moreiras, S.M., Páez, M.S., Lauro, C., Jeanneret, P. 2016. First cosmogenic ages for glacial deposits from the Plata range $\left(33^{\circ} \mathrm{S}\right)$ : New inferences for Quaternary landscape evolution in the Central Andes. Quaternary International. http://doi.org/10.1016/j.quaint.2016.08.041.

Moreno, P.I., Kaplan, M.R., François, J.P., Villa-Martínez, R., Moy, C.M., Stern, C.R., Kubik, P.W. 2009. Renewed glacial activity during the Antarctic cold reversal and persistence of cold conditions until 11.5 ka in southwestern Patagonia. Geology 37 (4), 375-378. http:// doi.org/10.1130/G25399A.1.

Placzek, C.J., Quade, J., Patchett, P.J. 2013. A 130ka reconstruction of rainfall on the Bolivian Altiplano. Earth and Planetary Science Letters 363, 97-108.

Ramírez, C.F., Gardeweg, M. 1982. Hoja Toconau, Región de Antofagasta: Carta Geológica de Chile, 1:250,000 Servicio Nacional de Geología y Minería de Chile, Boletín v. 54.

Rodbell, D.T., Smith, J.A., Mark, B.G. 2009. Glaciation in the Andes during the Lateglacial and Holocene. Quaternary Science Reviews 28 (21), 2165-2212. http://doi.org/10.1016/j. quascirev.2009.03.012.

Sagredo, E.A., Lowell, T.V., Kelly, M.A., Rupper, S., Aravena, J.C., Ward, D.J., Malone, A.G. 2016. Equilibrium line altitudes along the Andes during the Last millennium: Paleoclimatic implications. The Holocene. http://doi.org/10.1177/ 0959683616678458.

Sagredo, E.A., Rupper, S. Lowell, T.V. 2014. Sensitivities of the equilibrium line altitude to temperature and precipitation changes along the Andes. Quaternary Research 81 (2), 355 366. http://doi.org/10.1016/j.yqres.2014.01.008.

Schotterer, U., Grosjean, M., Stichler, W., Ginot, P., Kull, C., Bonnaveira, H., Francou, B., Gäggeler, H.W., Gallaire, R., Hoffmann, G., Pouyaud, B. 2003. Glaciers and climate in the Andes between the Equator and $30^{\circ} \mathrm{S}$ : What is recorded under extreme environmental conditions? In: Climate Variability and Change in High Elevation Regions: Past, Present \& Future. Springer Netherlands, pp. 157-175.

Smith, C.A., Lowell, T.V., Caffee, M.W. 2009. Lateglacial and Holocene cosmogenic surface exposure age glacial chronology and geomorphological evidence for the presence of coldbased glaciers at Nevado Sajama, Bolivia. Journal of Quaternary Science 24 (4), 360-372. http://doi.org/10.1002/jqs.1239.

Stichler, W., Schotterer, U., Fröhlich, K., Ginot, P., Kull, C., Gäggeler, H., Pouyaud, B. 2001. Influence of sublimation on stable isotope records recovered from high-altitude glaciers in the tropical Andes. Journal of Geophysical Research 106 (D19), 22613-22620.

Stone, J.O., Allan, G.L., Fifield, L.K., Cresswell, R.G. 1996. Cosmogenic chlorine-36 from calcium spallation. Geochimica et Cosmochimica Acta 60 (4), 679-692.

Vuille, M. 1999. Atmospheric circulation over the Bolivian Altiplano during dry and wet periods and extreme phases of the Southern Oscillation. International Journal of Climatology 19 (14), 1579-1600.

Vuille, M., Ammann, C. 1997. Regional snowfall patterns in the high, arid Andes. In: Climatic Change at High Elevation Sites. Springer Netherlands, pp. 181-191.

Vuille, M., Hardy, D.R., Braun, C., Keimig, F., Bradley, R.S. 1998. Atmospheric circulation anomalies associated with 1996/1997 summer precipitation events on Sajama Ice Cap, Bolivia. Journal of Geophysical Research: Atmospheres 103 (D10), 11191-11204. http://doi. org/10.1029/98JD00681.

Ward, D.J., Cesta, J.M., Galewsky, J., Sagredo, E. 2015. Late Pleistocene glaciations of the arid subtropical Andes and new results from the Chajnantor Plateau, northern Chile. Quaternary Science Reviews 128, 98-116. http://doi.org/10.1016/j.quascirev.2015.09.022. 
Wirsig, C., Ivy-Ochs, S., Akçar, N., Lupker, M., Hippe, K., Wacker, L., Vockenhuber, C., Schlüchter, C. 2016. Combined cosmogenic ${ }^{10} \mathrm{Be}$, in situ ${ }^{14} \mathrm{C}$ and ${ }^{36} \mathrm{Cl}$ concentrations constrain Holocene history and erosion depth of Grueben glacier (CH). Swiss Journal of Geosciences 109 (3), 379-388. http://doi.org/10.1007/s00015-016-0227-2.

Zech, R., Kull, C., Kubik, P.W., Veit, H. 2007. Exposure dating of Late Glacial and pre-LGM moraines in the Cordon de Doña Rosa, Northern/Central Chile $\left(\sim 31^{\circ} \mathrm{S}\right)$. Climate of the Past 3 (1), 1-14. http://doi.org/10.5194/cp-3-1-2007.

Zech, R., Zech, J., Kull, C., Kubik, P.W., Veit, H. 2011. Early last glacial maximum in the southern Central Andes reveals northward shift of the westerlies at $39 \mathrm{ka}$. Climate of the Past 7 (1), 41-46. http://doi.org/10.5194/cp-7-41-2011.

Zech,R.,Kull,C., Veit,H.2006.Late Quaternary glacial history in the Encierro Valley, northern Chile $\left(29^{\circ} \mathrm{S}\right)$, deduced from ${ }^{10} \mathrm{Be}$ surface exposure dating. Palaeogeography, Palaeoclimatology, Palaeoecology 234 (2), 277-286. http://doi.org/10.1016/j.palaeo.2005.10.011.

Zech, R., May, J.H., Kull, C., Ilgner, J., Kubik, P.W., Veit, H. 2008. Timing of the late Quaternary glaciation in the Andes from 15 to $40^{\circ}$ S. Journal of Quaternary Science 23 (6-7), 635-647. http://doi.org/10.1002/jqs.1200. 